\title{
Juosten vai juoksemalla? \\ Infiniittisten TEN- ja MALLA-rakenteiden semantiikkaa ja murrejakaumaa
}

\section{Johdanto}

Tässä artikkelissa selvitetään 2. infinitiivin instruktiivin (jatkossa TEN-rakenne tai -infinitiivi, esim. juosten, syöden) ja 3. infinitiivin adessiivin (jatkossa MALLA-rakenne tai -infinitiivi, esim. juoksemalla, syömällä) semanttista työnjakoa ja käyttöä lauseen kokoisissa konteksteissa. Suomen infinitiivirakenteita on fennistiikassa tutkittu eri näkökulmista mutta yhteisessä kognitiivisen kielentutkimuksen hengessä paljon (mm. Pekkarinen 2011; Visapää 2008; Kotilainen 2007; Herlin-Visapää 2005; J. Leino 2003). ${ }^{1}$ Kuitenkaan tämän artikkelin aiheina olevia TEN-rakennetta ja MALLA-rakennetta ja näiden keskinäistä suhdetta ei ole kunnolla verrattu aineistojen valossa, vaikka niiden käytössä on aina havaittu selvää päällekkäisyyttä (esim. Pokela 2005; Ontermaa 2005; Siro 1964, 113; Penttilä 1957, 497; Setälä 1922, 106, 109). ${ }^{2}$

Tässä artikkelissa keskityn TEN- ja MALLA-rakenteiden semanttisiin yhtäläisyyksiin ja eroihin, niiden motivaatioon sekä infinitiivirakenteiden murrejakaumaan ja -käyttöön, jota erityisesti ei ole aiemmin tutkittu. Aineisto on aiemmissa tutkimuksissa ollut valtaosin kirjoitettua yleiskieltä (esim. Pokela 2005; Ontermaa 2005; Saarnivaara 1998).

1 Kiitän tämän artikkelin käsikirjoitusversioiden kommentoinnista FinDiaSyn-hankkeen (Aluemurteiden näkökulma suomen syntaksiin, 2008-2011) jäseniä (Maria Vilkuna, Hannele Forsberg, Urpo Nikanne, Jaakko Leino, Mari Siiroinen, Miia Karttunen) sekä erikseen Ilona Herliniä. Kiitos kuuluu myös nimettömille arvioijille täsmällisistä parannusehdotuksista. Mahdolliset puutteet tai virheet ovat omiani.

2 Infinitiivejä on nimetty fennistisessä tutkimuksessa ajan saatossa lukuisin tavoin. Käytän jo mainittuja TEN- ja MALLA-infinitiivejä ennen kaikkea välttääkseni pitkiä ja kömpelöitä järjestysnumeroihin perustuvia nimityksiä. Konstruktiokieliopin mukaisesti esitän infinitiivikonstruktiot kapiteelein (esim. VÄYLÄ-, ANTAA- ja PERMISSIIVI-konstruktio). Ratkaisuni poikkeaa myös Ison suomen kieliopin (ISK, $\$$ 515) tavasta käyttää morfofonologista merkintää (esim. mAllA-rakenne). 2. infinitiivin instruktiivissa olen pitänyt mukana myös $t$-aineksen, joka siellä synkronisestikin useissa muodoissa yhä on (syö-den, juos-ten), ISK:ssa käytetään nimitystä en-rakenne (mp.). 
Seuraavassa on muutama murrenäyte TEN- ja MALLA-rakenteista.

(1a) ei siälä suksittaat tarvinnuk kyllä siälä käve... kävellem pääsi (LA, Laihia)

(1b) menimmä koko pitkät Runsool luhurat samaa asiaa jaakate (SMS, Nurmo)

(2a) sitä parannettii jollai lailla hakkaamalla (LA, Kankaanpää)

(2b) Huonompata heinee niitettiih hakkoomalla (SMS, Suonenjoki)

Esimerkeissä (1-2) näkyy TEN- ja MALLA-infinitiivien käyttöä erityyppisissä paikallisissa konteksteissa (Luojola 2007). ${ }^{3}$ Paikallisella kontekstilla tarkoitan tässä infinitiivien välitöntä käyttöyhteyttä finiittiverbin ympärille muodostuneessa lauseessa. Infinitiivit itsessään ovat vapaita adverbiaaleja (adjunkteja), joiden viimekätinen merkitys määräytyy niiden tulkinnasta käyttökontekstinsa perusteella. Niinpä TEN- ja MALLA-rakenteen kontekstuaalisen merkityksen aineistopohjainen kartoittaminen ja kuvaaminen on tämän artikkelin päätehtävä. Lisäksi murreaineisto sinänsä on tärkeässä asemassa, sillä sen avulla nähdään, kuinka infinitiivirakenteita on tosiasiassa puhutussa kielessä käytetty. Kirjoitetun kielen rakenteissa voi olla vääristymää suhteessa luonnolliseen normiin, sillä niitä on aikojen kuluessa pyritty valjastamaan ja ohjailemaan erilaisin kielenhuollollisin normein (ks. luku 2).

Vanhastaan näiden infinitiivirakenteiden merkitys on liitetty väljästi ja erikseen erittelemättä tavan ja keinon ilmaisemiseen (ks. tarkemmin luku 2). Molemmat ovat tulkittavissa tavan infinitiiveinä, mitä perustelen tarkemmin alaluvussa 4.1. TEN-rakenteella on aineiston valossa myös omia funktioitaan kuten (1b):ssä nk. oheisteko. Näitä käsitellään alaluvuissa 4.2 ja 4.3. Myös keinon tulkintaa tapaa esimerkkien (1a) ja (2a) perusteella molemmilta infinitiivirakenteilta, mikä tulee esiin alaluvussa 4.4.

Seuraavaksi taustoitan luvussa 2 sitä, mitä näistä infinitiivirakenteista on aikaisemmassa suomen kielen tutkimuksessa sanottu. Luvussa 3 kiinnitän tutkimuksen konstruktiokielioppiin ja selostan, kuinka ja millä perusteella varsinainen tutkimusaineisto on kerätty. Luvussa 5 tiivistän analyysiluvun tulokset ja tulkinnat.

\section{Tapa ja keino fennistisessä infinitiivitutkimuksessa}

TEN- ja MALLA-rakenteiden merkityserot eivät ole kovinkaan selvät aikaisemman tutkimuksen valossa: rakenteita ei ole systemaattisesti verrattu keskenään korpusaineiston valossa. On usein nostettu näkyviin vain ilmiöiden pääpiirteitä sellaisina, kuin ne vaikuttavat kielitajun varassa näyttäytyvän. Lisäksi on käytetty lähinnä kirjoitetun kielen korpuksia. Kirjakielessä ei-finiittisiä muotoja käytetään puhuttua kieltä tiheämmin, ja näin myös vertailupohjaa on ollut enemmän (esim. Ikola-Palomäki-Koitto 1989; Herlin-Leino-Visapää 2005; Siikki 1997, 4; Valijärvi 2007, 24-29). Kirjakieleen tai huoliteltuun yleiskieleen

3 Koska aineistoesimerkkejä on kolmesta erityyppisestä lähteestä, olen poistanut tai minimoinut erilaiset tarkkeet, erikoismerkit ja digitoinnista johtuvat korvausmerkit tai palauttanut ne lähimpään mahdolliseen konvention mukaiseen kirjoitusasuun. Korpusten erikoismerkit ovat keskenään poikkeavia, eivätkä ne vaikuta tässä tehtyyn syntaktis-semanttiseen analyysiin. 
on usein myös kohdistunut eriasteinen normatiivistaminen (esim. Kettunen 1949, 220221; Saarimaa 1967, 238-242; Kolehmainen 2003; Ontermaa 2005), eikä se aina ole antanut oikeaa kuvaa rakenteiden luonnollisen normin mukaisesta käytöstä.

Tapa ja keino semanttisina kategorioina ovat jääneet epäanalyyttisiksi. Suomen kielen kuvauksissa arkikielen sanat tapa ja keino on käsitteellistetty sisältöä sen tarkemmin erittelemättä. Kaiketi siksi esimerkiksi kielioppien ja (normatiivisempien) kielioppaiden lukuisat kuvaukset ovat summittaisia ja vaihtelevia (ks. myös esim. Karlsson 1995, 9-20; Lappalainen 1993, luku 3): Sekä TEN- että MALLA-rakenteen merkityksenä on voitu pitää tapaa (esim. Setälä 1922, 106, 109). Vaihtoehtoisesti vain jommankumman infinitiivin merkityksenä on voitu pitää sekä tapaa että keinoa (esim. Penttilä 1957, 497). On myös tunnustettu, "että [infinitiivien] instruktiivin ja adessiivin funktioissa on eroa, vaikka molemmat jotenkin ilmaisevat tapaa ja keinoa, mutta tätä eroa ei vielä ole täsmällisesti selvitetty" (Siro 1964, 113, lihavointi MH). (Ks. myös Saarnivaara 1998, 10-28.)

Varioivan murreaineiston varassa on mahdollisuus nähdä, minkä tyyppisiä semanttisia relaatioita infinitiivirakenteiden ja paikallisen kontekstin välille syntyy ja mikä on näiden merkitysten työnjako TEN- ja MALLA-rakenteiden kesken. Näin saadaan tarkempi kuva näiden infinitiivien erilaisista käyttötavoista ja merkityksistä, minkä myötä myös termeille tapa ja keino on mahdollista esittää teoreettisesti täsmällisempi sisältö.

Lähtökohtana voi pitää ISK:n luonnehdintaa, että adverbiaalimääritteinä toimivat infinitiivit "ilmaisevat laajassa mielessä tapaa: ne kuvaavat sitä, miten hallitsevan verbin ilmaisema tilanne toteutuu" (ISK, $\ 515$ ). Tämä ei vielä erottele tapaa ja keinoa. Sama koskee lauseenvastiketutkimuksessa (esim. Ikola 1974) käytettyjä infinitiivirakenteiden parafraaseja niin että ja siten että.

Käsitteellisenä erona pidän sitä, että keino (sekä väline) ottaa muutoksen "välikappaleena" osaa voimadynamiikka- tai kausaatioketjuun, mutta tapa jättäytyy näiden ulkopuolelle (J. Leino 2001, 78). Keino edustaa välittävää tapahtumaa jonkin tilannetyypin lähtö- ja lopputilojen välillä, kun taas tavassa on kyse siitä, että yhteen ja samaan tilanteeseen (verbiprosessiin) liitetään kuvailevia piirteitä (ks. Taylor 1995, 46-51; König 1995, 65-66). Tavan ja keinon semantiikka liittyy siis miten-tulkintojen kahteen eri ulottuvuuteen: keino liittyy tilanteiden kehittymiseen eli sekventiaalisuuteen (tai syntagmaattisuuteen) ja tapa kuvailemiseen ja luonnehtimiseen (tai paradigmaattisuuteen). Tässä artikkelissa tutkin sitä, miten TEN- ja MALLA-rakenteiden aineistosta nousevat lingvistiset funktiot asettuvat tähän käsitteelliseen jakoon.

Kausaalisuudessa on yleisesti kyse siitä, että temporaalisesti peräkkäisten asiaintilojen välillä on suhde, jossa edeltävä asiaintila on tai on tulkittavissa syyksi ja sitä seuraava asiaintila tämän seuraukseksi. Tämä aiheutussuhde voi olla löyhän implisiittinen (mahdollistava) tai tiukan konventionaalinen (aiheuttava) (Herlin 1998, luku 3.1). Kausaalisuus perustuu maailmassa toimivien olioiden kykyyn kohdistaa voimaa, vastaanottaa vaikutuksia, ylittää vastuksia ja saada aikaan muutoksia. Maailman voi hahmottaa olevan alati muutoksen tilassa, ts. periaatteessa päättymättömässä kausaatioketjussa. Tämän kausaatioketjun hahmottaminen on mahdollista eri karkeusastein useammallakin eri tavalla: Ensinnä itse kausaalisuuden voi nähdä spatiaalisuuden laajentumana, asiantilojen 
välisenä tai olioiden välisenä ( $k$. Croft 1991, 159-163). Toiseksi päättymättömästä kausaatioketjusta on mahdollista yksilöidä eripituisia jaksoja ja näiden jaksojen sisältä eri olioita ja tapahtumia (Croft mts. 163-165). Kolmanneksi kausaatioketjut pitävät sisällään erilaisia kausaatiotyyppejä (esim. Talmy 2000, luku 8).

Keskeisin kielellinen keino kausaatioketjun käsitteellistämiseen on verbien avulla tapahtuva asiantilojen yksilöinti ja verbin ja yleisemmin kuvatun tilanteen erilaisten osallistujaroolien kielentäminen. Näistä muodostuvat erilaiset (kielikohtaiset) syntaktiset rakenteet, jotka eri prototyyppisyyden astein edustavat erilaisia kausaatiotyyppejä. Kun muutosten taustalla olevien voimien ja vastavoimien kokonaisuus huomioidaan, voidaan Talmyn (ks. 2000, 409-413) tapaan puhua voimadynamiikasta kausaalisuuden yleistyksenä. Esimerkiksi lause Syysmyrskystä huolimatta Keijo viimein pääsi soutamalla ( soutaen) saareen kuvaa sellaista voimadynaamista tilannetta, jossa Keijon etenemiseensä tuottama voima kokee syysmyrskyn vastavoimana (vastatuuli, aallokko, vihmova sade ym.). Adverbiaali soutamalla nimeää kuvatussa voimadynaamisessa tilanteessa sitä toimintaa (voimaa), jolla syysmyrskyn tuottama vastus voitetaan. Se on voimadynamiikan osana keino saareen pääsemiseksi. Se myös ilmentää kausaaliketjun kielentämiseen valittua karkeusastetta (ks. myös Croft 1991, 166): tilanneyhteydestä tiedetään kausaatioketju, jossa Keijo kohdistaa voimaa airoihin, airot syrjäyttävät vettä ja veden syrjäytymisen seurauksena vene liikkuu. Tämä maailmantieto on konstruoitu keinon adverbiaalilla. Maailmaan sijoittuvien asiaintilojen kausaatioketjut voidaan havaita hyvinkin tarkasti, mutta voimadynamiikan kielellisen kuvauksen kannalta on olennaista, mitkä osat tällaisesta ketjusta kielennetään, ts. miten kausaalisuus konstruoidaan. Tässä suhteessa voimadynamiikan osina voidaan kielentää niin verbien kuvaamat prosessit (soutamalla) kuin substantiivien kuvaamat oliotkin (vene, airot).

Nikanne (1997) on suomen infiniittisten adjunktien temporaalisia suhteita eri aikakerrosten avulla kuvatessaan käsitellyt myös TEN- ja MALLA-infinitiivejä. MALLA-infinitiivi esitetään intuitioon vetoavasti keinon ilmaisuna, jonka merkitys liittyy kausaalisuuteen (mts. 349-352). Koska finiittiverbin ja infinitiivin keskinäiset temporaaliset suhteet ovat hieman eri asia kuin tavan ja keinon merkitykset (mts. 349), niin Nikanne jättää juuri näiden tulkintojen suhteen tutkimuksen vielä avoimeksi. Lisäksi hän lähtee siitä, että "adjunktiverbin [esim. juuri TEN- ja MALLA-rakenteiden] tietty morfologinen rakenne on kytketty tiettyyn merkitykseen" (mts. 339, 354). Esitän tässä vaihtoehtoisen ajatuksen, että TEN- ja MALLA-rakenteella ei välttämättä ole morfologisen rakenteen ja tietyn konventionaalisen merkityksen suoraviivaista kytkentää. Sen sijaan näiden infinitiivirakenteiden merkitys perustuu paikallisen lausekontekstin säännönmukaisuuksiin ja ennen kaikkea infinitiivirakenteen ja finiittisen verbin ja sen täydennysten keskinäiseen semanttiseen relaatioon. Infinitiivirakenteiden merkityksiä tulee siis tarkastella ennen muuta paikallisessa kontekstissaan. Yhdellä morfologisella infinitiivimuodolla voi olla useampia käyttötapoja (polysemia). ${ }^{4}$

4 Kullakin yksittäisellä infinitiivirakenteella on toki konkreettisessa käyttökontekstissaan oma (osin idiosynkraattinen) tilannemerkityksensä. Tämä on kuitenkin analyysin kannalta syytä pitää erillään niistä yleistettävissä olevista merkityksistä, jotka edustavat kielen systeemisiä konventionaalistumia. 


\section{Teoria ja aineistot}

Käsittelen kuvaamiani infinitiivirakenteita konstruktioina, ja tutkimukseni liittyykin kon-struktiokielioppiin. Siinä kielen yksiköt kuvataan eriasteisesti skemaattisina tietorakenteina erilaisten rakenne- ja merkityspiirteiden avulla. Näiden tietorakenteiden oletetaan edustavan erilaisten kognitiivisten hahmotusten lingvistisiä vastineita, käsitteistyksiä.

Konstruktiokieliopin eri teoreettiset suuntaukset jakavat ajatuksen siitä, että konstruktiot ovat muodon ja merkityksen (tai rakenteen ja funktion) yhteenliittymiä. Niitä voi olla erikokoisia ja eri abstraktisuusastein. (Mm. Fillmore 1989; Goldberg 2006; Croft 2001; Bergen-Chang-Narayan 2004; Steels-van Trijp 2011.) Konstruktioilla pyritään kuvaamaan kattavia yleistyksiä siitä kielellisestä tiedosta, jonka oletetaan olevan kielenpuhujille sekä sosiaalisesti jaettua (ja sikäli normatiivista) että kognitiivisesti jäsentynyttä varantoa. Konstruktion käsitettä ja teorian lähtökohtia on käsitelty väljemmin useassakin lähteessä (mm. Fried-Östman 2004; J. Leino 2003, luku 3; J. Leino 2010; Kotilainen 2007, luku 2; Herlin-Kotilainen 2012; Hilpert 2014).

Aineistolähteinä olen käyttänyt digitaalista Lauseopin arkistoa (LA), digitaalista Muoto-opin arkistoa (DMA) sekä Suomen murteiden sanakirjan painettuja osia 1-8, (SMS). Kunkin lähteen aines koostuu suomen vanhoista pitäjämurteista.

Infinitiivirakenteet ovat - lukuun ottamatta ehkä TA-infinitiivin lyhyttä muotoa (esim. syödä) ja MA-infinitiivin sisäpaikallissijoja (esim. syömään, syömässä) - yleisesti ottaen puheessa huomattavasti harvinaisempia kuin kirjoitetussa kielessä (Ikola ym. 1989; Herlin-Leino-Visapää 2005, 17). Taulukossa 1 näkyy TEN- ja MALLA-rakenteista saatu korpusaineisto lukuina.

Taulukko 1. TEN- ja MALLA-infinitiivien määriä LA-, DMA- ja SMS korpuksissa.

\begin{tabular}{|c|c|c|c|c|c|c|}
\hline \multirow{3}{*}{ korpus } & \multicolumn{3}{|c|}{ TEN-rakenne } & \multicolumn{3}{c|}{ MALLA-rakenne } \\
\cline { 2 - 7 } & raakadata (n) & seul-\% & aineisto $(\mathrm{n})$ & raakadata $(\mathrm{n})$ & seul-\% & aineisto (n) \\
\hline LA & 182 & 59 & $\mathbf{7 4}$ & 177 & 7 & $\mathbf{1 6 4}$ \\
DMA & 2137 & 49 & $\mathbf{1 0 9 5}$ & 1419 & 27 & $\mathbf{1 0 2 8}$ \\
SMS & 352 & 23 & $\mathbf{2 7 2}$ & 812 & 6 & $\mathbf{7 6 5}$ \\
\hline$\Sigma$ & 2671 & 46 & $\mathbf{1 4 4 1}$ & 2408 & 18 & $\mathbf{1 9 5 7}$ \\
\hline
\end{tabular}

Raakadatalla tarkoitan sitä bruttoainesta, joka edellä käsitellyistä aineistolähteistä on kaiken kaikkiaan saatu käytetyillä hakukriteereillä. ${ }^{5}$ Se ei kuitenkaan ole sama asia kuin var-

5 Eri korpuksista on raakadata saatu seuraavin hakukriteerein: Lauseopin arkiston hakulausekkeet: $<$ inf2 ins adv:li $>$ (TEN) ja <inf3 ade adv:li> (MALLA). Digitaalisesta muoto-opin arkistosta on käyty läpi signumit 747 (TEN) ja 751 (MALLA). Suomen murteiden sanakirjan osien 1-8 (kirjainväli A-kurvottaa) digitaalisessa käyttöliittymässä olen käyttänyt säännöllisiä lausekkeita .*te ja .*en|.*ten (TEN) sekä .*mal|.*mäl ja .*mala|.*mälä ja .*malla|.*mällä (MALLA). 
sinainen tutkimusaineisto (tai "nettoaineisto"), jonka edustama luku kummankin rakenteen osalta kussakin aineistolähteessä on esitetty taulukon 1 oikeanpuoleisessa palstassa lihavoituna. Seulontaprosentti (seul-\%) kuvaa sitä, kuinka monta prosenttia raakadatasta on siirretty syrjään erilaisia, tämän tutkimuksen kannalta irrelevantteja infinitiivien käyttöjä (ks. metodista Itkonen-Pajunen 2010, 29-32). Seulontaperusteena on käytetty semantiikkaa: kaikki sellaiset TEN- ja MALLA-infinitiivien käytöt, jotka tuntuvat kuvaavan muuta kuin (kontekstissaan täsmentyvää) tekemisen tapaa laajassa mielessä (ks. luku 2), on siirretty sivuun. Tällaisia tapauksia ovat muun muassa seuraavanlaiset ilmaukset:

(3a) kyä se kävi niil liukkaaksi siähen nähäre (LA)

(3b) sen tunsin jo pienestä pittäen- iha (LA)

(3c) Kesän tullen se [sairas] siitä janahistaotu ja on nyt riski ukko (SMS)

(3d) Paskin nyv vähä holtaten sitä hölötystäs ruokapöyrässä! (SMS)

(3e) ostamalla ne ruutit pantii (LA)

Esimerkin (3a) siähen nähäre 'siihen nähden' tyyppiset adverbistuneet tai adpositioituneet kiteytymät kuten asiasta tehden 'varta vasten', minun muistaeni 'muistaakseni' ja aikaa voittaen on karsittu aineistosta pois. Samoin (3b):n tapaiset, eriasteisesti adpositioituneet ja inkoatiivismerkityksiset leksikaalistumat, kuten ruveten, lähtien, alkaen, on jätetty syrjään (ks. myös Saarnivaara 1998, 29-37).

Esimerkki (3c) edustaa marginaalista TEN-infinitiivin temporaalista käyttöä (illan tullen, päivän tullen, tiukan paikan tullen, myös mennen tullen), jota voisi kutsua olosuhteen infinitiiviksi (ISK, $\$ 519$ ). Tällaisia ei MALLA-infinitiiviltä löydy aineistosta ollenkaan. TEN-infinitiivilläkään näitä ei ole kuin puolisen sataa koko aineistossa. Rakenne rajoittuu lähinnä tulla-verbiin. Esimerkin (3d) direktiivinen ilmaustyyppi panna tehden on raakadatassa suhteellisen taajaan esiintyvä hämäläis-satakuntalaisilla murrealueilla. Se ja sen oletettavasti itämurteisempi vastine (3e) on edellisen tapaan jätetty myös tarkastelun ulkopuolelle (Kiuru 1989, 411). Näiden lisäksi seulaan on jäänyt sekalainen joukko erilaisia muita leksikaalistumia, kiteytymiä ja jopa yksittäisiä kerrannaisesiintymiä niin TEN- (sanoen, vuorotellen, läpimitaten, näin ollen ym.) kuin MALLA-rakenteestakin (kuolemallas 'kuolemaisillasi', yhdellä kaatamalla ym.). Joskus poisjätön syynä on ollut yksinkertaisesti liian vajaa konteksti tai muu vaikeatulkintaisuus.

Edellisten kaltaisista tapauksista on muodostunut viimekätinen seulontaprosentti. On erikseen huomattavaa, että TEN-rakenteen osalta seulontaprosentti lähentelee keskiarvoa 50, vaikka kummankin infinitiivin raakadatan kokonaismäärä on samaa suuruusluokkaa. TENinfinitiivin taipumus leksikaalistumiin on jo vanhastaan tunnistettu (Genetz 1891, 49-50). Myös Ikola, Palomäki ja Koitto (1989, 341-344) esittävät, että pelkästään leksikaalistumat TEN-infinitiivin osalta sekä Lauseopin arkiston murre- että yleiskielisessä aineistossa ovat lähes kolmanneksen luokkaa. MALLA-infinitiivin osalta seulontaprosentti jää alle 20:n. Valijärven (2007, luvut 6-7) sanomalehtiaineistoa koskevassa tutkimuksessa suomen konverbit (eli vapaina adverbiaaleina toimivat ei-finiittiset muodot) asetetaan leksikaalistumisen ja kieliopillistumisen suhteen kolmiasteiselle jatkumolle (low, medium, high). Tämäkin tutkimus vahvistaa sen, että juuri TEN-infinitiivillä on paljon erilaisia kiteymiä ja leksikaalistumia: 
yllättäen, suoraan sanoen, olettaen (että), kuullen, nähden, verraten, alkaen, tieten, päättäen jne. MALLA-infinitiivillä niitä on taas erityisen vähän. (Valijärvi mts. 225-232.)

Seulotun tutkimusaineiston varassa keskityn seuraavassa luvussa 4 infinitiivirakenteiden paikalliseen kontekstiin, lähinnä lauseen kokoisiin jaksoihin. Tällöin TEN- ja MALLAinfinitiivin funktioiden kannalta huomio kohdistuu finiittiverbin, sen argumenttien ja infinitiivirakenteen keskinäisiin suhteisiin.

\section{Kahden infinitiivin monet kasvot}

Tässä luvussa kuvaan TEN- ja MALLA-rakenteiden korpuksesta nousevia eri käyttöjä hahmottaakseni, miten ne jäsentävät luvussa 2 esitettyä käsitteellistä jakoa tapaan ja keinoon. Kuvaan infinitiivien ja lausekontekstin välille syntyvien relaatioiden semantiikkaa luvuissa 4.1-4.4. Näin saadaan käsitys tekemisen tapaan liitettyjen merkitysten kirjosta korpusaineiston valossa sekä merkitysten distribuutiosta kahden infinitiivirakenteen suhteen. TEN- ja MALLA-rakenteille yhteisiksi erottuvat suurimpana ryhmänä varsinaista tapaa kuvaavat ilmaukset (4.1). TeN-rakenteen omaksi käytöksi erottuu oheisteon tai oheistoiminnan kuvaus (4.2). Lisäksi aineistosta nousee myös muita harvinaisia vain TEN-infinitiiville ominaisia käyttöjä (4·3). Molemmilla infinitiiveillä on käyttöä myös keinoksi tulkittavissa ilmauksissa, ja MALLA-rakenteella voi nähdä olevan myös oma, menettelytavaksi nimeämäni alaryhmä (4.4).

\subsection{Varsinaiset tavan infinitiivit}

Aineiston perusteella taajimmin esiintyvä ja ongelmattominkin infinitiivien merkitys on sellainen, jota voisi luonnehtia varsinaiseksi tavaksi. Hyvä lähtökohta on Königin (1995, 66) huomio, että " [- - ] both verbs relate to one and the same event or action”. Tätä käyttöä on runsaasti kummallakin infinitiivillä.

(4a) ne [lampaat] tulit hyppiev vastarintoja jo siältä (LA, Laihia)

(4b) hyvin se [sairas vanhus] hoeperrellen käveli (SMS, Kajaani)

(4c) tuli tualta lotojen kärmes (DMA, Ylihärmä)

Esimerkit (4) kuvaavat liiketapahtumaa, joissa TEN-infinitiivin verbi leksikaalisella merkityksellään kuvaa tarkemmin liikkumista. Hyvin usein kuvataan juuri liikettä ja liikkumista (aineistosta vajaa neljännes). Olennaista on se, että finiittiverbin ja infinitiivin välillä on hyponymia-suhde (esim. Lyons 1979, 291-295), joka voi olla abstraktin finiittisen yleisverbin ja infiniittisen perusverbin (4a), finiittisen perusverbin ja infiniittisen koloratiivisen verbin (4b) tai finiittisen yleisverbin ja infiniittisen koloratiivisen verbin (4c) välillä. Koloratiiviverbit ovat ääntä mukailevia onomatopoeettisia verbejä (esim. sihisee, kopahtaa, töräyttää) tai muuten kuin äänneasullaan kuvailevia deskriptiivisiä verbejä (esim. käpristelee, luimii, nököttää) (ks. Mikone 2002; Larjavaara 2007, 188-189; Hamunen 2012 ja niissä mainitut lähteet). 
Hyponymia on semanttista sisältyvyyssuhdetta (luokkajäsenyyttä): TEN-infinitiivien (hyppien, hoeperrellen, lotojen) liikkeen merkitys sisältyy jo yläkäsitteeseen (hyperonyymiin), joka esimerkeissä 4 on finiittimuotoinen verbi (tulit, käveli, tuli), mutta lisäksi alakäsitteen (hyponyymin) leksikaalinen merkitys sisältää tarkempaa tietoa nimenomaan liikkeen tavasta (ks. esim. Palmer 1981, 85-87; Larjavaara 2007, 143-145). Juuri tavan merkitys näyttäisi olevan verbileksikossa hyponymia-suhdetta synnyttävä tekijä (Pajunen 2001, 33-38). Tästä seuraa myös se Königin $(1995,65)$ havainto, että ”[--] converbs [= mm. tässä käsiteltävät infinitiivit] specify a dimension or parameter implicitly given in the meaning of the verb in the main clause".

Vaikka verbilekseemien karkea jako yleis-, perus- ja koloratiivisiin verbeihin on kytköksissä hyponymiaan, se on kuitenkin periaatteessa kategorioinnin prototyyppisyyteen perustuva oma dimensionsa: havainnoinnin ja käsitteellistämisen kannalta perusverbit (kävellä, juosta, syödä, juoda, itkeä ym.) edustavat kognitiivisesti prototyyppisiä perustoimintoja ja sikäli myös toiminnan kielellisen luokittamisen perustasoa. Tämän yläpuolelle jäävät skemaattisemmat yleisverbit (liikkua, tulla, mennä, olla ym.) ja alapuolelle toimintaa ja tilanteita yksityiskohtaisemmin kuvaavat koloratiiviverbit (hoiperrella, kömytä, hotkia, tihrustaa ym.) (ks. Rosch 1978; P. Leino 1993, 36-40).

Myös MALLA-infinitiivillä on paljon vastaavaa käyttöä, joista seuraavat ovat esimerkkien (4) kaltaisia.

(5a) ei olnu autoi, mut kyl päästi muuto liikkel ja kevelemäl vaa menti (LA, Kisko)

(5b) se [kihdin vaivaama] niij jäpöittelemällä kävelöö (SMS, Konginkangas)

(5c) ehäm minä olem [liikkunut] muuta että häntä kompuroittemalla mennee (DMA, Juupajoki)

Esimerkeissä (4) ja (5) infinitiivi ja finiittiverbi kuvaavat samaa toimintaa. Tätä usein vahvistaa myös niiden esiintyminen lähellä toisiaan. Muutakin toimintaa kuin liikkeen kuvaamista esiintyy.

(6a) älä noih hahmimalla syä (SMS, Luopioinen)

(6b) se oekeeh hihkumalla naoroi, oekeeh huoneet kajaht (SMS, Konginkangas)

(6c) se [kalja] ol sillä laella tehty, möykyttään (DMA, Sonkajärvi)

(6d) ivaten tomppeli viisaammastansap puhuu (SMS, Suoni)

Periaatteessa mikä tahansa tyypillinen perustoiminto kuten syöminen (6a), nauraminen (6b), tekeminen (6c), puhuminen (6d) tulee aineiston valossa kyseeseen, kunhan verbien välillä on, tai erityisesti kun niiden välille käyttöyhteydessään syntyy, hyponymiatyyppinen suhde ja ne kuvaavat samatarkoitteisen subjektin yhdenaikaista toimintaa. Voi pikemmin ajatella, että TEN- ja MALLA-rakenteiden ominaisuus konstruktioina on sellainen, että ne liittyvät hallitsevan rakenteen (argumenttirakennekonstruktion) verbin kuvaamaan toimintaan ja näin hyponyyminen suhde on ennen kaikkea syntaksin tuottamaa.

Varsinaista tapaa kuvaavien TEN-rakenteiden viisi yleisintä hallitsevaa verbiä ovat tulla, mennä, kulkea, kävellä/käydä ja olla ja MALLA-rakenteiden mennä, tehdä, tulla, 
viedä ja palaa. Vastaavasti viisi yleisintä TEN-infinitiiviä ovat kävellen/käyden, joutuen, juosten, varoen, hypäten/hyppien/hypellen ja MALLA-infinitiiviä kävelemällä/käymällä, kantamalla, konttaamalla, kaatamalla ja soutamalla tai hiihtämällä. Liikkeen kuvaaminen painottuu siis molemmilla rakenteilla.

Kun asetetaan TEN- ja MALLA-rakenteiden varsinaista tapaa kuvaavat käytöt vanhan pitäjäjaon mukaiselle kartalle (ks. liitteet $1 \mathrm{a}-\mathrm{b}$ ), voidaan todeta, että tämä funktio on molemmalla infinitiivirakenteella koko Suomen kattava. ${ }^{6}$ Kun tarkastellaan alueellista jakaumaa tarkemmin, huomataan kuitenkin, että kartassa (1a) TEN-rakenteen varsinaisen tavan funktiot näyttävät painottuvan hiukan enemmän läntisiin murteisiin, kun taas MALLA-rakenteen jakauma kartassa (1b) on tasaisempi ja myös laajempi kuin TEN-rakenteella. Näillä infinitiiveillähän varsinaisen tavan merkitys on aineistossa samaa kokoluokkaa: TEN-infinitiivillä 829 esiintymää ja MALLA-infinitiivillä 889 esiintymää.

Tulkitsen runsasta alueellista päällekkäisyyttä sisältävän jakauman vahvistavan, että varsinaisen tavan merkityksen suhteen infinitiivirakenteet ovat keskenään indifferenttejä. Toinen aavistuksen odotuksenvastainen tulos koskee MALLA-rakenteen jakaumaa, jossa ei kartan (1a) TEN-rakennetta vastaavalla tavalla ilmene painottumista itämurteisiin. Jos näin olisikin ollut, niin se antaisi selvemmät perusteet päätellä jakauman luonteen heijastelevan mahdollista muotojen vanhaa itä-länsi-murrejakaumaa. Tähän viittaisi ainakin Kiurun (1989) tutkimus MA-infinitiivin olosijoista kirjasuomen historiassa. Käy ilmi, että itäisen murrepohjan tulo kirjoitettuun suomeen varhaisnykysuomen kaudella toi muassaan myös MALlA-rakenteen (mts. 440-441). Kiuru toteaa (mts. 441), että "2. inf. instruktiivia ja 3. inf. adessiivia käytetään eri murteissa samassa funktiossa", mutta kartoista (1a-b) nähdään, että tämän aineiston valossa samamerkityksisyyttä on myös samoissa murteissa ja samoilla murrealueilla.

Yhtenä TEN- ja MALLA-rakenteiden lyhyyden takeena on muun muassa samasubjektisuus finiittiverbin kanssa (ks. myös murteiden temporaalirakenteesta Lindén 1961). Tekemisen tapaa tarkemmin luonnehtivat infinitiivit asettuvat usein finiittiverbin läheisyyteen. Tällä tavoin usein yhdessä esiintyvien verbien kesken infinitiivi saattaa adverbistua. Tällaisia on tapaa ilmaisevissa yhteyksissä ylivoimaisesti enemmän TEN-rakenteella kuin MALLA-rakenteella: se pittää nii taeten tehä (LA, Juuka), jos siähen [kuoppaan] pimmeinpäin rookaa kropsahtaan nin eiks mahra kalpaten käyrä (SMS, Tyrvää), ei, kyl se [ketunloukku] nyy o jo joute ollu (DMA, Hinnerjoki). Muita adverbistuneita tapaa kuvaavia TEN-rakenteita ovat muun muassa varoen, juurta jaksain, yllättäen, sivumennen, vuorotellen, vähitellen, leikiten. Huomattavan moni adverbistuneiksi tulkitsemistani muodoista kuvaa tapaa jonkin mentaalisen toiminnon tai muun abstraktimman modaliteetin valossa, eikä verbien välillä näin välttämättä ole hyponymia-suhdetta, joka on varsinaiselle tavalle tyypillistä.

Yleisesti infinitiivien erilaisissa leksikaalistumissa tunnus- ja sijamorfeemin produktiivinen suhde verbikantaan on selvästi hämärtynyt ja leksikaalistumalle on kehittynyt usein

6 Kiitän Anneli Hännistä (Kotus) avusta karttojen laatimisessa. 
oma, ei-kompositionaalinen merkityksensä. Edellä kuvatuissa enemmän tai vähemmän adverbistuneissa tapauksissa näkyy ainakin rakenteen kiteytymistä (konsonanttivartaloisuus) ja sanaluokan vaihtoa vartaloverbin hämärryttyä (esim. kalpaten < murt. kalpata). Toisinaan on kuitenkin vaikea tehdä selvää eroa leksikaalistuman ja idiomaattisen tai muuten frekventin ilmauksen välille (Valijärvi 2007, 228-230). Tällaisiksi olen tulkinnut kävelemistä kuvaavan käyden mutta myös kävellen ja kävelemällä. Muuten MALLA-rakenteella on hyvin vähän leksikaalistumia. Tähän tulkintaan saattaa vaikuttaa se, että nämä infinitiivit esiintyvät aineistossa usein tulla- ja mennä-verbien kanssa, ja nämä verbiketjut ovat kokonaisuuksina idiomaattistuneet (vrt. tulla järkiinsä, mennä mönkään yms.).

Mikäli verbien välillä ei ole hyponymia-suhdetta, kyseeseen tulee ns. vartalontoistorakenne, jota esiintyy vain MALLA-infinitiivillä: Ne [kutojat] polkemal polkvat elestakaist että tul koukulliist (SMS, Heinola), ette olluv viskuria muta ne...[jyvät] heitettiin heittämällä vaan (LA, Pirkkala). Tämä rakenne näyttää rajoittuvan pääasiassa itämurteiden alueelle ja osin keski- ja pohjoispohjalaisiin murteisiin sekä sydänhämäläiselle alueelle. Aineistossa sitä esiintyy noin 250 tapausta. Se kuvaa tapaa korostamalla toiminnan intensiteettiä, toisteisuutta tai muuta piirrettä (M. Räsänen 2010, 116-118).

\subsection{Oheisteon TEN-infinitiivi}

Mikäli infinitiivi ja finiittiverbi eivät kuvaa olennaisesti samaa verbiprosessia kuten varsinaista tapaa kuvaavat ilmaustyypit eikä verbien välillä ole hyponymia-suhdetta, voi tulkintoja olla kontekstista riippuen useita. Vain TEN-infinitiiville yksinomaiseksi eriytynyttä käyttöä edustavat erilaiset oheisteon tai oheistoiminnan infinitiivit, joita kuvaavat esimerkit (7).

(7a) ja Tilta tul itkiim meille ja sano että tuota lähe lähet tuota kahtommaa (LA, Leppävirta)

(†b) nuarisoseurataloollem meni väkiä, ne meni krääkyjej ja melskaten tästä, mä täs istuuj ja (LA Ylihärmä)

(7c) koerahi ihan irmistellen [irvistellen] söe sitä pettuleipää (SMS, Rautavaara)

Esimerkeille (7) on yhteistä se, että infinitiivi ja finiittiverbi ovat eri prosesseja mutta samasubjektisia; ne rakentavat yhteistä kokonaistapahtuman kuvausta. König (1995, 65-66) luonnehtii oheistekoa (attendant circumstance) seuraavasti: "[they] should be used for cases where two independent events or actions are involved, either of which could be stopped without affecting the other, but which manifest a unity of time and place and thus a "perceptual unity"'. Samaa ei voi sanoa varsinaisen tavan ilmauksista, koska esimerkiksi (6a):sta älä noih hahmimalla syä (SMS, Luopioinen) ei voi käsitteellisesti poistaa syömistä vaikuttamatta samalla hahmimiseen. Königin tarkoittama havaintokokonaisuus ("perceptual unity”) rakentuu siis väljemmälle suhteelle, jossa verbit voivat olla eri käsitealueilta.

Oheisteossa finiittisen liikeverbin kylkiäisenä esiintyy yleensä mentaalista toimintaa (7a) tai puheaktia ( $7 \mathrm{~b}$ ) kuvaava TEN-infinitiivi: poika tuli poratej (DMA, Loimaa), pehtoori tuli kiroten (DMA, Loimaa). Näille esimerkeille on ominaista toimintojen samanaikaisuus. Liikeverbi on näissä melkeinpä norminmukaisesti finiittinen. Tästä löytyy vain 
yksi päinvastainen tapaus: [Poika] viheltel karate [= juosten] (DMA, Laitila, vrt. karkasi vihellellen). Taulukossa 2 näkyy aineistossa oheisteon tulkinnan saaneiden TEN-rakenteiden kokonaismäärä ja se, millaisten finiittisten verbien kanssa oheisteon TEN tyypillisesti esiintyy (verbiluokittelusta ks. Pajunen 2001).

Taulukko 2. Oheisteon TEN ja yhdistyvien verbityyppien variaatio aineistossa.

\begin{tabular}{|l|c|l|}
\hline \multicolumn{3}{|c|}{ TEN-rakenne (n = 1441) } \\
\hline verbityypit & & \multicolumn{2}{|c|}{} \\
$\left(\mathrm{V}_{\text {FIN }}+\mathrm{V}_{\text {TEN }}\right)$ & $\mathrm{n}$ & esimerkki (oheisteon TEN) \\
\hline LIIKE + TEKO & 63 & se meni mun erelläni kropsien kaikki marjat (SMS, Nurmo) \\
LIIKE + PUHEAKTI & 49 & aivan kaikki palo ja minä huutain sieltä tulej (LA, Toholampi) \\
LIIKE + FYSIOL. & 25 & ne [rengit] tuli niin nauraen sieltä tallista (DMA, Virrat) \\
LIIKE + KOGN. & 13 & siält sentään tulivattem murjottaen Olka ja Jalmari (DMA, Vihti) \\
LIIKE + AISTIHAV. & 11 & koettakee männä kahtoen sielä suola [suolla] (SMS, Sulkava) \\
LIIKE + muu & 10 & jäät joesta menöö kovina ja komiasti helääten (SMS, Kurikka) \\
muita & 39 & [He taitavat sen] tapelte syär (DMA, Hinnerjoki) \\
\hline \multicolumn{1}{|c|}{$\Sigma$} & $\mathbf{2 1 0}$ & \\
\hline
\end{tabular}

Taulukosta 2 nähdään, että oheisteko ei ole TEN-rakenteen aineistossa kokonaisuudessaan kovin yleinen. Se on kuitenkin TEN-rakenteen ominta eriytynyttä käyttöä, joka on hyvin marginaalista MALLA-rakenteelle. Huomionarvoista on myös se, että hyvin usein aineiston esimerkeistä finiittiverbinä on liikeverbi. Kaikenlaisten liiketapahtumien kuvaaminen on tietenkin tällaisessa kerronta-aineistossa tavallista, mutta se ei selitä sitä, miksi juuri liikeverbi on lähes poikkeuksetta finiittimuodossa. Kielitajun varassa tuntuu siltä, että verbien finiittisyyden kääntäminen tuottaa outoja tai kieliopillisuuden suhteen kyseenalaisia ilmauksia: ${ }^{7}$

(7a') ?Tilta tullen itki meille ja sano (yleiskielinen toisinto 7a:sta)

(7b’) ?ne mennen krääkyj ja melskasi tästä (yleiskielinen toisinto $7 \mathrm{~b}: s t a ̈)$

Uskoakseni kyse on infinitiivien kielioppiin liittyvästä semanttisesta rajoituksesta. Finiittinen liikeverbi kuvaa TEN-infinitiiviä salientimpaa, havaittavampaa ja dynaamisempaa toimintaa (myös Saarnivaara 1998, 54-55, 57). Se kuvaa spatiaalista väylälle sijoittuvaa toimintaa, kun vastaavasti oheisteon TEN kuvaa muuta, ei-spatiaalista toimintaa. Semanttinen rajoite kuuluisi niin, että havaittavampi ja inherentisti spatiaalisista piirteistä keskeisen profilinsa saava toiminta olisi aina finiittimuotoista.

7 Murre-esimerkkien toisintaminen kielitajun varassa saattaa näyttäytyä metodisena ongelmana, mutta käytän seuraavassa argumentoinnin vertailumateriaalina muutamien esimerkkien yleiskielisiä toisintoja. Tällainen käytäntö irrottaa analyysin empiirisestä aineistosta ja tekee siitä jossain määrin spekulatiivista. Esimerkit kuitenkin auttavat ymmärtämään sitä teoreettista johtelua, jonka havainnollistavaksi heuristiikaksi ne on tarkoitettu. Tätä koskeva argumentointi on puhdasta teoretisointia ja siihen tulee suhtautua näin ollen sopivalla varauksella. Kiitän kriittisestä huomiosta nimetöntä arvioijaa. 
Palaan taulukon 2 esimerkkeihin ja esitän muutamista niistä fabrikoidun yleiskielisen toisinnon: ?sieltä sentään tullen murjottivat Olka ja Jalmari ja ?koettakaa katsoa mennen siellä suolla. Edellä hahmotetun semanttisen rajoitteen perusteella voidaan spekuloida, että kyseiset esimerkit kuulostaisivat oudoilta, koska yhtäl̈ltä kognitiivisten ja fysiologisten toimintojen sekä aistihavaitsemisen ja toisaalta konkreettisten spatiaalisten toimintojen (kuten liike) välillä on luonnollisia havaittavuuseroja. Näin ollen ei-liikettä kuvaavat toiminnot edustaisivat vähemmän salientimpia toimintoja juuri kognitiivisen havainnoinnin kannalta ja ne jäisivät siksi helpommin toiminnan kuvauksessa taustalle. Näissä verbi-ilmauksissa liikeverbin finiittimuotoisuus ei olisi niinkään vapaasti valittu tapa käsitteistää kuin näitä verbi-ilmauksia koskeva semanttinen rajoite, jossa kognitiivisesti salientimpi toiminta merkitään finiittiseksi ja vähemmän salientimpi infiniittiseksi. TEN-rakenteella kuvattu toiminta on nimenomaan toimintaa suhteessa finiittiverbin kuvaamaan toimintaan ja sikäli alisteista (alisteisuudesta ks. Cristofaro 2003, 25-50).

Sen sijaan esimerkiksi lausuman se meni mun erelläni kropsien kaikki marjat (SMS, Nurmo) toisinto se mennen minun edelläni kropsi kaikki marjat tuntuu käyvältä. Verbi kropsia ('käsillään kerätä, kaapia, haalia') kuvaa transitiivista toimintaa mutta myös liikettä. Nyt finiittisyyden vaihdettavuuden mahdollistaa nähdäkseni se, että salienttisuus tekojen välillä neutraalistuu. Kumpikin verbi kuvaa olennaisesti spatiaalisessa tilassa tapahtuvaa ja havaittavaa liikettä. Lisäksi tällaiset tapaukset voidaan kai tulkita myös perättäisiä toimintoja kuvaaviksi.

Jos tarkastellaan vielä taulukon 2 niitä oheistekoa tai -toimintaa kuvaavia tapauksia, joissa finiittiverbinä on muu kuin liikeverbi, niin huomataan (in)finiittisyyden käännettävyyden käyvän paikoin hankalammaksi: moni [lapsi] lukkee makkaillen satukirjuja (DMA, Jällivaara), mutta ${ }^{*}$ moni lukien makailee satukirjoja. Huomataan, että transitiivisen finiittiverbin suoran objektin ei tarvitse olla verbin vieressä, mutta (adjunkti-) infinitiivin objektin yleensä täytyy (ks. kuit. Vilkuna 1989, 230-246). Sanajärjestykseltään manipuloitu yleiskielinen toisinto olisi käypä, siis moni makailee lukien satukirjoja. Argumenttirakenteen osallistujatkin ovat siinä määrin verbikohtaisia, että erityisesti transitiiviset tilanteet eivät finiittisyyden suhteen järkevästi aina käänny: sehän [uskovaisten tervehdys "jumalan terve"] sanothin aivan halaten (SMS, Rovaniemi), muuta ${ }^{*}$ sehän [sama] sanoen aivan halattiin.

Lukuun ottamatta edellisen tapaisia tapauksia muuta kuin liikettä kuvaavat TENrakenteen sisältävät ilmaukset tuntuvat olevan pääasiassa (in)finiittisyydeltään käännettäviä, minkä tulkitsen johtuvan siitä, että salienssi-eroa tekojen välillä on verbeissä hankala, jollei mahdoton, nähdä. Esimerkiksi meinaakaham miehet räyhäten saarat tahtonsal läpitte (DMA, Kurikka) ja meinaavatkohan miehet räyhätä saaden tahtonsa lävitse kuvaavat pitkälti samaa asiaintilaa pienellä käsitteistyserolla. Tämä ohjaa viimein ajattelemaan, että salienssi-ero kävisi ennen kaikkea liikeverbien ja muiden verbien kesken. Liikeverbit spatiaalisina ovat kuvattavia kokonaistilanteita kehystäviä. Liikettä kuvaavissa konteksteissa on usein erilaisia liikkeeseen liittyviä kehysadverbiaaleja. Ne osaltaan rakentavat kuvaa toiminnan yleisistä spatiaalisista puitteista, siis muun, TEN-rakenteella 
kuvatun oheistoimimisen kehyksestä: [Jaska] kuluki teheren kaikemmoista kiusaa siälä navitas (DMA, Laihia). Näin TEN-rakenteella kuvattu toiminta tulee helposti tulkituksi juuri finiittiverbin luomassa (toiminta)kehyksessä oheistekona ja "lisätietona". Kielitajun varassa edellä kuvattua ajatusta ei voi suoraan verifioida (tai falsifioida), mutta se, että yleiskielisiksi kääntämieni toisintojen kaltaisia ilmauksia ei käyttämästäni korpusaineistosta löydy, jossain määrin oikeuttaa spekuloinnin.

Koska finiittisyys ja infiniittisyys asettavat verbit deiktisesti (esimerkiksi tempusmerkinnän kannalta) epäsymmetriseen suhteeseen, eivät verbien keskinäiset aikasuhteet välttämättä ole yksioikoiset. Tämä aikaansaa usein kontekstuaalisesti motivoituvia tulkinnallisia kytkentöjä verbien välille niin, että kyse ei ole aina pelkästään tekojen päällekkäisyydestä tai yhdenaikaisuudesta. Esimerkiksi (7c):ssä on selvä seurauksellisuuden merkitys ('koira irvistää, koska pettuleipä on pahaa'). Myös niissä tapauksissa, joissa finiittisen liikeverbin kanssa käy transitiivinen TEN-infinitiivi, toiminnan tarkoituksellinen luonne korostuu: kum minäkin oon ollu aikuunen niin, niin, joululehtijä, kulijettihin kaupatej (DMA, Ilmajoki). Tällaisissa ei aineiston perusteella aina ole kyse liikkumisen kanssa täysin samanaikaisesta tekemisestä, vaan infinitiivin kuvaaman toiminnan toisteisuudesta, habituaalisuudesta ja tarkoituksellisuudesta ('kuljetaan paikasta toiseen tekemään jotain'). ${ }^{8}$ Liikkeen ja muun infiniittisen toiminnan samanaikaisuus (esim. kuluki sitten vartiooren) tai eriaikaisuus (esim. kuluki kyläs hiarojej) on selvästi jatkumomainen ja osin pragmaattisestikin tulkittava asia (vrt. Nikanne 1997, 348-349; Pokela 2005, 306-307).

Oheisteon tulkinnan saavat MALLA-infinitiivin käytöt eivät yleiskielessä kuulosta mahdollisilta (esim. ${ }^{\star}$ Tilta tuli itkemällä (vrt. 7a), ${ }^{\star}$ koirakin irvistelemällä söi (vrt. 7c). Aineistossakin on näin tulkittavia tapauksia vain parisenkymmentä: silloi ne men, kiroomal [naimisiin] (DMA, Orimattila), puihan toiset seisomallakii (DMA, Vehkalahti, vrt. Onikki-Rantajääskö 2001, 272), yks heikkomeininkinen [heikkomielinen] kiärsi, Tormif Frans, hän tuli veisaamalla talojen pihaan (SMS, Pomarkku). TEN-infinitiivi on tällaisissa esimerkeissä MALLA-infinitiiviä odotuksenmukaisempi, mikä näkyy myös aineistossa.

Kartan 2 TEN- ja MALLA-rakenteen oheisteon funktioiden murrelevikkistä näkyy, että TEN-rakenteen esiintymät ovat melko lailla hajautuneet. Tämähän on selvästi juuri TENrakenteen ominta käyttöä, eikä mitenkään alueellisesti rajautunut erikoisuus. Kokonaisuudessaan oheisteko ja -toiminta ovat käytetyssä aineistossa lukumääräisesti melko pieni ryhmä (ks. taulukko 2), ja luultavasti tästä syystä esiintymistiheyskään ei ole kovin korkea. Oletus oli, että MALLA-rakenteen oheisteon esiintymät olisivat jollain tavoin keskittyneet itämurteiden puolelle, mutta odotuksenvastaisesti nämä parisenkymmentä esiintymää hajautuvat ympäri eri murrealueita. Tämä tuntuu vaikealta selittää. Esiintymien jakaumakaan ei vihjaa mistään dialektologisesti merkille pantavasta.

8 Tämä TEN-rakenteen käyttö on lähellä TA-infinitiivin translatiivia eli nk. tarkoituksen infinitiiviä ( $k a$ lastaakseen, nikkaroidakseen). 


\subsection{Harvinaisempia TEN-rakenteita}

Aineistossa on myös joitain nk. status-rakenteita (esim. meiv väänsin hampaat riuskui ['kirskuen'] kämment (DMA, Somero)) tai muita ilmauksia, joissa TEN-rakenteella on jokin oma argumentti. Sillä voi olla oma subjekti kuten edellisessä ilmauksessa, objekti (sormia nuolten ['hyvin mielellään'] se lähti sen kans (DMA, Himanka)) tai jokin adverbiaali (Kesäkuumalla myö jätkytettiin huulilla pöristen kiilijäisem pörinää (SMS, Lappajärvi)). TEN-infinitiivin omaa argumenttia yhdistää semanttisesti finiittiverbin subjektiin se, että niiden tarkoitteet ovat tällaisissa tapauksissa keskenään osa-kokonaisuus-suhteessa (meronymia). Tällainen argumentti on voitu jättää myös ilmipanematta (peäski [pääsky] lenttää [esim. siipi] vettä hippoen (SMS, Kuhmo)). Rakennetta voi pitää oheisteon infinitiivinä. Se kuvaa väljästi tapaa sikäli, että TEN-rakenne tuo vain lisäkuvailua finiittiverbillä kuvattuun tapahtumaan.

Mainitsen vielä kaksi marginaalista TEN-rakenteen käyttöä. Ensiksi aineistossa on vajaat kolmisenkymmentä tapausta, joissa TEN-rakenteelle voi kontekstissaan tulkita seurauksellisuuden merkityksen: satajehhan [sataenhan] suvi tullee (DMA, Juupajoki), siit tul aika paksua saippuaa keittäev vaa (DMA, Orimattila): sataa $\rightarrow$ tulee suvi ja x keittää saippuaa $\rightarrow$ saippuasta tulee paksua. Etenkin elollistarkoitteisten referenttien toimintaa kuvaavissa tapauksissa tulkinnassa korostuu vaikuttamisen merkitys, esimerkiksi ei kukkookaak käskiel laula (DMA, Laihia). Tällaista käyttöä on myös MALLA-rakenteella, esimerkiksi ei tyät tekemällä lopu (DMA, Kuhmoinen). Lauseenvastiketutkimuksessa näitä on pidetty nk. modaalirakenteina (esim. Ikola 1974, 44-47). Tällaiset käytöt kiinnittyvät miten-tulkinnoissa enemmän keinoon; infinitiivit kuvaavat sitä vaikuttamisen tapaa, jolla finiittiverbillä kuvattua toimintaa pyritään edistämään. Usein nämä ovat sananlaskuja, mikä voi kieliä siitäkin, että tällainen infinitiivien käyttö ei ole enää produktiivista.

Toiseksi erikoinen on anaforinen sitä tehden -rakenne, jonka tehtävä on koota edeltävästä tekstikontekstista erikseen täsmentyvä jakso tai episodi ikään kuin laajennetuksi kuvaukseksi hallitsevalle rakenteelle: [ne lyhteet kun ne sijottii ne pantiin sitte yks lyhek kiännettiij jalakalyhteeks, noin ikkeesti, kippuraa, ja se tuohon noe sittet toesija nui, toenev vastapiätä] $]_{\mathrm{i}}$ ja [sitä tehe $]_{\mathrm{i}}$ ympärin nuin ikkeesti, ympäriisäv vua, sel lyhtee ympäri, hajallee että kuivu, että ei yhteen, pinkkaan, joutunuh hajaal, nii että piäsöö tuul läp (LA, Riistavesi). Tällainenkin asettuu tavan piiriin laajasti ymmärrettynä (miten jokin tapahtuu), mutta sen tarkempi merkitys täsmentyy kontekstikohtaisesti. Edellisen esimerkin tulkintana voisi olla keino (ks. luku 4.4): jotain tekemällä (sitä tehe) saadaan lyhteissä tapahtumaan jokin muutos (että kuivu). Samanlaista käyttöä ei löydy aineistosta MALLA-rakenteelta. Sen sijaan läheisenä rakenteena voi pitää TESSA-infinitiiviä (tehdessä). Vaikka sen käyttö murteissa on väljemmin temporaalista, eli hallitsevan verbin tekeminen sijoitetaan TESSA-rakenteen ilmaiseman tekemisen "sisään", on sen myöhempi kirjakielinen kehitys synnyttänyt mm. konditionaalisia käyttöjä, jotka käyvät jo hyvin lähelle edellistä esimerkkiä (ks. Lindén 1961; Herlin-Kotilainen 2005).

Tällaisia sekalaisia, vähäkäyttöisiä tai jopa kertailmauksia on tulkintani mukaan TENrakenteella ja MALLA-rakenteella aineistossani yhteensä ehkä parisensataa. 


\subsection{Keinon ja menettelytavan infinitiivit}

Kuten todettua, lukumääräisesti taajimmin esiintyvä funktio MALLA- ja TEN-infinitiivillä on aineiston valossa varsinaisen tavan ilmaiseminen (ks. s. 131-132). Mikäli tähän lisätään vielä usein tavan piiriin kuuluvat vartalontoistorakenteen esiintymät (ks. s. 134), tutkimusaineiston valossa karkeasti puolet MALLA-rakenteen käytöstä voisi katsoa liittyvän tavan ilmaisemiseen luvussa 4.1 kuvatulla tavalla.

Lisäksi MALLA-infinitiivi on omiaan erilaisissa tavoitteellista ja päämäärähakuista toimintaa kuvaavissa yhteyksissä (esim. 9).

(9a) se on otettun nin tuota keinottelemalla karhu aenaeh (LA, Suomussalmi)

(9b) minussa ei oos sitä, sitä, uskova ensikeä, että puhumalla soahaa mikä paranemmaa (LA, Mikkelin mlk)

(9c) oli semmosia vesilätäköitä ne päästiin kiärtelemällä ku ne, tolta pitkim... vainioita, syrjiä (LA, Pirkkala)

(9d) see kert selvittim puhumalk kyl (DMA, Honkilahti)

Esimerkkien (9a-d) finiittiverbit kuvaavat kukin sellaisia voimadynaamisia asetelmia, joissa lausuman kuvaamaa toiminnan tai tapahtuman tavoiteltua toteutumista on estämässä tai vaikeuttamassa jokin joko implisiittinen tai eksplisiittinen vastavoima: (9a):ssa karhu, (9b):ssä asiat (joiden huonon tolan presupponoi verbi parantua), (9c):ssä vesilätäköt ja (9d):ssä jokin implisiittiseksi jäävä tilanne. MALLA-rakenne kuvaa näissä tapauksissa keinoa tällaisen vastavoiman tavoitteelliseksi ja tarkoitukselliseksi ylittämiseksi tai voittamiseksi sekä päämäärän saavuttamiseksi. Varsinaisen tavan funktiossa infinitiivirakenne jää voimadynamiikan ulkopuolelle kuvailemaan tapahtumia, mutta keinon ilmaisuna vastaavasti liittyy osaksi voimadynaamista kuvausmallia (ks. myös J. Leino 2001, 78-79; Talmy 2003, luku 7).

Aineistossa MALLA-rakenteella on 737 keinoksi tulkittavaa tapausta. Myös TEN-rakenteella on tällaista käyttöä, mutta tulkintani mukaan kokonaisuutena tarkastellen huomattavasti vähemmän kuin MALLA-rakenteella, 152 tapausta: kyllä siälä käve... kävellem pääsi (LA, Laihia), sei [kuorma] lähteny pukaten eikä vettäin (SMS, Liminka). Edellä ja jatkossa keinon funktiosta sanottu pätee myös tähän TEN-infinitiivin käyttöön.

Aineistossa keinon funktiossa MALLA-rakenteen viisi yleisintä hallitsevaa verbiä ovat saada, tehdä, päästä, parantua/parantaa ja tulla ja TEN-rakenteella tehdä, tulla, päästä, parantua/parantaa, loppua. Näissä painottuvat transitiiviset tekemisverbit, joihin liittyy olennaisesti muutoksen merkitys (esim. tehdä, parantaa) ja sellaiset voimadynaamiset verbit, joiden käsitteistämiin tilanteisiin liittyy jonkinlaisen implikoidun vastavoiman tai esteen kumoutuminen (esim. saada, päästä). Nämä ovat otollisia konteksteja juuri keinon infinitiiveille, joista aineistossa viisi yleisintä on MALLA-infinitiivillä ampumalla, ostamalla, tekemällä, hirttämällä ja vetämällä ja TEN-infinitiivillä kävellen/käyden, syöden, nuollen, soutaen ja puhuen/kysyen/käskien.

Kartoista $(3 a-3 b)$ voidaan kai aika yksiselitteisesti todeta, että keinon funktio on selvästi kartan (3a) perusteella juuri MALLA-rakenteen ominta käyttöä. Esiintymät ovat tällä 
aineistomäärällä kartassa ( $3 a$ ) jo melko tasaisesti jakautuneet koko maahan ja suuremmatkin pitäjäkohtaiset esiintymämäärät jakautuvat niin, että selityksen vaativia keskittymiä ei ole havaittavissa. Sen sijaan kartassa (3b) on näkyvissä hienoista TEN-rakenteen rajautumista läntisen Suomen alueelle (lounais-, satakuntalais-, hämäläis- sekä eteläpohjalaisiin murteisiin). Itämurteiden puolella olevat esiintymät näkyvät joiltain osin sijoittuvan myös vanhan itä- ja länsimurteiden etelärajan tuntumaan. Selvästi ainakaan sydän-Savon seudulla TEN-rakennetta ei aineiston perusteella paljonkaan viljellä tässä funktiossa, vaan käytössä on (ollut) todennäköisemmin MALLA-rakenne. TEN-rakenteelle harvinaisempi keinon funktio tuntuu jakautuvan alueellisesti merkitsevällä tavalla. Karttaa (3a) kannattaa myös verrata kartan (1a) TEN-rakenteen jakaumaan.

Myös seuraavissa esimerkeissä (10a-b) on voimadynaamisia piirteitä. Nekin kuvaavat muutostilanteita jonkin esteen tai vastavoiman voittamisena. Finiittiverbinä on tilanmuutosta kuvaavia verbejä kuten esimerkiksi aueta, edistyä, hävitä, isota, jatkaa, jäähtyä, katketa, kummentua ('tulla kummemmaksi'), loppua, lähteä, muuttua, parantua, puhdistua, pehmentyä, saada (joksikin), vanheta yms. Niissä subjektitarkoite on epätoiminnallinen, mutta intransitiivinen finiittiverbi kuitenkin hahmottaa muutoksen edellyttävän aktiivista toimintaa. Tämä ilmaistaan MALLA-infinitiivillä.

(10a) juolaheinä ei häviäm muuta kuj järijestään kuokkimalla (DMA, Virrat)

(10b) kyllä se [lika] pesemällä lähtee (DMA, Tammela)

Esimerkeissä finiittiverbillä ja infinitiivillä on eri subjekti (ks. T. Itkonen 1974, 381; 1975, 32-33). MALLA-infinitiivillä on geneerinen (nolla)subjekti ja finiittiverbin ilmisubjekti on infinitiivin objektina. Esimerkkien tapahtumat näyttäytyvät nimenomaan yleisen tietämyksen valossa, kuinka lika lähtee tai juolaheinä hävitetään. Muuten infinitiivi tulkitaan aina finiittiverbin kanssa samasubjektiseksi. MALLA-infinitiivi kuvaa keinoa, jolla ei-toivotusta (alku)tilanteesta päästään toivottuun (loppu)tulokseen.

Keinoa kuvaavan MALLA-rakenteen semanttisena alatyyppinä voisi vielä pitää niin sanottua menettelytavan infinitiiviä. Tämä ryhmä ei kuitenkaan rajaudu rakenteellisesti mitenkään selvästi erilleen keinoa yleisesti kuvaavista MALLA-rakenteista. Kuten tiedetään, murreaineiston esimerkeissä kerronta liittyy kiinteästi agraarikulttuurin tapoihin, perinteisiin ja toimiin. Niinpä MALLA-infinitiivi kuvaa erilaisten konkreettisten teko- ja valmistamisverbien kanssa yhtä mahdollisesti monista käytettävissä olevista menettelytavoista eri toimintamahdollisuuksien repertuaarissa (esim. 11).

(11a) lippoomallakin kalastaa [jotkut] (DMA, Kuru)

(11b) matteita kanssa [pyydettiin] nuijimalla (DMA, Uurainen)

(11c) ne sillä laella iskettämällä kae niitä [kaloja] ottoa (DMA, Uurainen)

Kaikki esimerkkien (11) tapaukset kuvaavat erilaisia kalastamisen (menettely)tapoja. Muita pyydystämistapoja olisivat esimerkiksi onkiminen, tuulastaminen, käestäminen ja uisteleminen. Näissä esimerkeissä MALLA-infinitiivi ei niinkään kuvaa sellaista "välittävää" tekoa tai toimintaa, joita erilaiset voimadynaamiset asetelmat (esim. 9) ja subjektitarkoitteen (tilan)muutosta kuvaavat tilanteet (esim. 10) edellyttävät. MALLA ei myöskään 
esitä tavankaltaista luonnehtivaa kuvausta tapahtumasta. Menettelytavan merkityksessä korostuu se, että subjektitarkoite hallitsee infinitiivirakenteella nimetyn toiminnan erityisenä teknisenä suorituksena ja että infinitiivillä kuvattu verbi nimeää juuri erityisen toimintatavan.

Myös esimerkiksi viljan käsittelyä kuvataan aineistossa mitä moninaisimmilla menettelytavoilla: pohtamalla, tappamalla [saatiin jyvät irti], viskaamalla, loukuttamalla [erotettiin ruumenet]. Ylipäänsä erilaiset valmistamisprosessit pitävät sisällään vaihtoehtoisia toimintatapoja tai vaihtoehtoisia ilmaisutapoja samoille toiminnoille. Tällainen ilmentää sekä vanhoja alueellisia ilmaisueroja (esim. tappaa vs. hakata viljaa) että ennen kaikkea sitä, että vanhat tavat ja käytännöt ylipäätään sijoittuvat murrekerronnassa infinitiiveihin. Finiittiverbeillä kuljetetaan kerrontaa ja toiminnankuvausta eteenpäin sekä selitetään kuulijalle hankalaksi oletettuja seikkoja. Infinitiiveillä tuodaan esiin vanhoja toimintatapoja: minä muistan sen kun puitiin kotimökillä riihiä ja siellä erotettiij jyvät ruumenista viskaamalla sanottii viskattii (LA, Temmes).

Aineiston perusteella tällaiset infinitiivin tulkinnat liittyvät oikeastaan vain MALLAinfinitiivin käyttöön. Sikäli havainto on odotuksenmukainen, että myös keino on aineiston perusteella nimenomaan MALLA-infinitiivin keskeisfunktioita (ks. s. 139), ja menettelytapaa voi pitää keinon alalajina. Lisäksi vain adessiivilla on selvä välineen merkitys, mikä näissä MALLA-rakenteen käytöissä korostuu (ks. Jääskeläinen 2004).

\section{Lopuksi: yhteenveto TEN- ja MALLA-rakenteiden semantiikasta}

Alaluvuissa 4.1-4.4 olen käynyt läpi käyttämäni murreaineiston TEN- ja MALLA-rakenteiden erilaisia miten-tulkintoja ja niihin vaikuttaneita tekijöitä. Eri tulkintojen lukumääräistä jakaumaa aineistossa kuvaa karkeasti taulukko 3. Taulukkoon on asetettu infinitiivirakenteiden käyttöfunktioita aineiston perusteella yleisimmistä harvinaisempiin. Taulukko ei pyri olemaan tutkittujen infinitiivirakenteiden funktioiden täydellinen luettelo eikä laskennallisesti täsmällinen, vaan tarkoitus on näyttää rakenteiden tavallisimpien käyttöjen kokoluokittaiset pääpiirteet sellaisena kuin ne aineistossa näyttäytyvät.

Taulukko 3 on jaettu kahtia siten, että taulukon lihavoidut luvut edustavat aineiston yleisimpiä tulkintoja. Nämä ovat (varsinainen) tapa, keino sekä menettelytapa. Koska olen halunnut esittää kuvauksen mahdollisimman selville tapauksille, niin tähänastisessa aineistonkäsittelyssä ei ole korostunut näiden funktioiden jatkumoluontoisuus. Aineiston kuvauksissa edellisissä luvuissa esitetyt lukumäärät näiden funktioiden osalta ovat siksi osaksi kompromisseja. Esimerkiksi TEN-rakenteen tavan funktiota kuvaava luku on esitetty taulukossa 3 alaindeksillä varustettuna $\left(829_{49}\right)$. Tämä tarkoittaa sitä, että (varsinaiseksi) tavaksi ja keinoksi tulkittavien TEN-infinitiivien käyttöjen väliin jää karkeasti indeksillä kuvattu määrä näiden funktioiden hankalasti tulkittavaa kaksitulkintaisuutta. Vastaavasti MALLA-rakenteen funktiot tavan ja keinon sekä keinon ja menettelytavan 
Taulukko 3. Infinitiivirakenteiden tulkinnalliset jatkumot ja eriytyneet käytöt.

\begin{tabular}{|c|c|c|}
\hline semanttinen relaatio & TEN-rakenne $(\mathrm{n}=1441)$ & MALLA-rakenne $(\mathrm{n}=1957)$ \\
\hline (varsinainen) tapa & $\mathbf{8 2 9}_{49}$ & $\mathbf{8 8 9}_{109}$ \\
keino & $\mathbf{1 5 2}$ & $\mathbf{7 1 3}_{70}$ \\
menettelytapa & $(2)$ & $\mathbf{3 0 4}$ \\
oheisteko & 198 & $(17)$ \\
olosuhde & 47 & - \\
seuraus & 27 & $(9)$ \\
syy/edellytys & $(3)$ & $(21)$ \\
(vähäkäyttöiset/hapaks- & $(\approx 180)$ & $(\approx 10)$ \\
tyyppiset) & & \\
\hline
\end{tabular}

osalta sisältävät karkeasti indeksilukuja vastaavia määriä monitulkintaisia tapauksia. ${ }^{9}$ (Myös Saarnivaara 1998, 103.)

On huomattava, että taulukossa 3 jatkumomaisuus näkyy selvemmin MALLA-rakenteella kuin TEN-rakenteella, mikä heijastanee diakronisesti adessiivin instrumentaalisen merkityksen (adnominaalinen väline ja adverbaalinen keino) kehittymistä ja siirtymistä instruktiivin tilalle (ks. Huumo 1997, 72-77). Kummallekin infinitiiville (varsinaisen) tavan merkitys on tavallisinta. Tässä suhteessa infinitiivirakenteet ovat funktioltaan indifferenttejä eikä murrejakaumakaan anna selvää kuvaa niiden (historiallisista) suhteista (vrt. kuit. Saarnivaara 1998, 85). En kuitenkaan ota tässä kantaa, mikä mahdollisesti olisi tavan ja keinon funktioiden diakroninen suhde ja kehityskulku (vrt. Heine-Kuteva 2002, $87,180-181)$.

Tavan ja keinon suhteen kaksitulkintaisia voisivat olla seuraavantyyppiset TEN- ja MALLA-rakenteiden käytöt:

(12a) toiset meni [laskiaisena] keppi käres konkaten saunha (SMS, Alahärmä)

(12b) Pak kurottaen, ei se nin allaal o ette stä kurottamalla uletu (SMS, Tyrvää)

Esimerkissä (12a) kaksitulkintaisuuden voi ajatella syntyvän siitä, että konkkaaminen kuvaa ennen kaikkea liikkumisen tapaa ja keinon piirteitä tulee mukaan kepin kanssa kulkemisesta ja koko toiminnan intentionaalisuudesta suhteessa esitettyyn uskomukseen. Vastaavasti esimerkissä (12b) kurottaminen kuvaa tekemisen tapaa ottamisen tai tarttumisen tyyppinä ja keinon piirre liittyy ylettymisen dynaamiseen modaalisuuteen ja siis voimadynamiikkaan.

Myös keinon ja menettelytavan välillä on tulkinnallista liikkumavaraa:

9 Monitulkintaisia tapauksia esittävät alaindeksiluvut ovat sikäli "virtuaalisia" lukuja, että tapaukset sisältyvät taulukon 3 lihavoituihin lukuihin ja nimenomaan kukin tapaus kompromissina tapauskohtaisesti vain toiseen kahden eri tulkinnan välillä (tapa $\sim$ keino tai keino $\sim$ menettelytapa). 
(13a) Hammaskasvajain parannettii voitelemal siarrasvaa pöhistyneesee leukaperää (SMS, Sippola)

(13b) kaskamalla se Sammeli-vainaa paransi reumatismia (SMS, Vittanki)

Esimerkissä (13a) sianrasvan voiteleminen leukoihin oli keino parantaa kivulias hammaskasvain eli saada aikaan terveydentilan muutos ja samalla se oli yksi alkeellisen hammashuollon menettelytavoista. Samantyyppinen tulkinta sopii esimerkkiin (13b), jossa kaskaminen kuvaa aivan erityistä parannusmenetelmää (menettelytapa), jossa pohkeisiin tehtiin pieniä haavoja ja niistä valutettiin sitten verta pois. Tällä uskottiin parannettavan reumatismia (keino).

Juuri tässä mielessä TEN- ja MALLA-rakenteiden semantiikka on paljossa kontekstista emergoituvaa. Tarkoitan sitä, että tiettyjen kontekstuaalisten piirteiden kasautuessa infinitiivien merkitys kehkeytyy suhteellisesti selvärajaisemmin prototyyppiseksi tavaksi tai keinoksi (tai menettelytavaksi). Vastaavasti funktioiden häilyvyys johtuu siitä, että infinitiivirakenteiden prototyyppisiä merkityksiä luovat piirteet eivät kasaudu vaan voivat suorastaan sekoittua. Tällöin rakenteiden merkitys voi perustua tulkitsijankin tilanteiseen valintaan. Kummankin infinitiivin osalta tavan tulkintaa tukevat yhdessä sellaiset piirteet kuin infinitiivin ja finiittiverbin hyponymisyys, verbien lineaarinen lähekkäisyys, samasubjektisuus ja liikkeen tai muun konkreettisen toiminnan kuvaus (ks. luku 4.1). Vastaavasti keinon tulkinta kehkeytyy siitä, että verbien välillä ei ole hyponymia-suhdetta, subjektitarkoite (sama- tai erireferenttinen) on volitionaalinen ja paikallinen konteksti kuvaa voimadynaamista tai teelistä tapahtumaa. Keinon tulkinta koskee valtaosin MALLArakennetta ja menettelytavan tulkinta yksinomaan sitä. Menettelytavan tulkinta rajoittuu konkreettisiin teko- ja valmistamisprosesseihin, joissa MALLA-infinitiivin verbi nimeää jonkin teknisen toiminnan. (Ks. luku 4.4.)

Taulukossa 3 lihavoimattomat luvut edustavat TEN- ja MALLA-rakenteiden eriytyneitä ja harvinaisempia käyttöjä. Lähinnä huomionarvoisia ovat TEN-rakenteen oheisteon tulkinta (ks. luku 4.2), joka perustuu sille, että finiittiverbi ja infinitiivi kuvaavat toisiinsa vaikuttamattomia prosesseja sekä vieläkin suppeakäyttöisempi olosuhteen infinitiivi (ks. luku 4.3). Eriytyneet käytöt vähälukuisuudestaan huolimatta kasaantuvat pitkälti TENrakenteelle. Tämän oletan johtuvan siitä, että TEN-infnitiivi on MALLA-infinitiiviä vanhempi, jolloin voi odottaa löytävän myös kieliopillistumiskehityksen aikaansaamia reliktejä sekä erikoistuneita mutta epäproduktiivisia konstruktiotyyppejä (ks. esim. Huumo 1997).

Huomionarvoista on, että marginaalisempia käyttöjä on kuitenkin kokonaisuutta ajatellen vähän. Varsinkin seurausta ja syytä tai edellytystä kuvaavissa tilanteissa infinitiivirakenteen ja finiittiverbin kuvaamilla tapahtumilla on tyypillistä tavan ja keinon kuvausta selvemmin ajallisesti perättäinen ja näin myös jollain lailla väljempi suhde. Esimerkiksi seurauksen merkityksessä TEN-rakennetta on vain vajaa kolmekymmentä (ja MALLArakenteella vielä vähemmän): se lopussa peästi [huono-onnisen ripille] kun se isämeijän oppi hätäräppösestin nuim papin aotellen (SMS, Puolanka) eli oppi rukouksen ja pääsi sitten ripille osittain papin auttamana. Tilanne ei tule kuvatuksi niinkään papin tavoitteellisena 
toimintana saada konfirmaatio suoritetuksi (keino) kuin yhtenä myötävaikututtavana toimintana, jonka seurauksena "läpimeno" mahdollistui. Samoin syyn tai edellytyksen käyttöä on vähän, hieman enemmän MALLA-rakenteella kuin TEN-rakenteella: kuumentamalla voejjaan sitäkiit takkoo (DMA, Vehmersalmi) eli 'kun ensin kuumennetaan, niin sitten voidaan takoa' Raudan kuumentaminen on keino päästä kuumatakomaan eli se on takomisen edellytys mutta ei varsinainen takomisen keino tai menettelytapa (kuten vasaralla iskemällä prässäämällä tyssäämällä ym.) TEN- ja MALLA-rakenteiden käytöt ovat selvästi keskittyneet taulukon 3 lihavoituja lukuja vastaaviin merkitystehtäviin, jotka ovat hallitsevan rakenteen kanssa temporaalisesti samanaikaisten tai päällekkäisten prosessien kuvausta.

TEN- ja MALLA-rakenteen funktiot siis keskittyvät osittain limittyviin merkityksiin ja eräisiin lähinnä TEN-rakenteen erikoiskäyttöihin, ja näitä käyttöjä yhdistää finiittiverbillä kuvattavaan prosessiin ajallis-paikallinen samuus. Lisäksi käsillä olevien infinitiivirakenteiden aineiston pohjalta laaditut funktiokohtaiset murrejakaumat (ks. kartat $1 \mathrm{a}-3 \mathrm{~b}$ ) eivät kokonaisuutena osoita päivänselvää alueellista distribuutiota, joka vahvistaisi taustalla oletetun rakenteiden murrelähtöisyyden. Ennakkoon oletin, että TEN-rakenne olisi painottunut enemmän länteen ja MALLA-rakenne selvemmin itään. Kiurun (1989) kirjasuomen kehitystä kuvaava tutkimus tarjoaa mielestäni riittävästi viitteitä tällaiselle oletukselle, koska keinon MALLA astui kirjakieleen silloin, kun itämurteetkin alkoivat siinä näkyä eikä toisaalta sen puuttuminen vanhasta kirjasuomesta selvästikään johtunut lähtökielten mallista vaan siitä murrepohjasta, jota kääntäjät käyttivät (erit. mts. 442).

Tutkimuksessaan Kainuun murteiden kaasussyntaksi myös Seppo Räsänen (1972) esittää runsaasti esimerkkejä juuri keinon MALLA-infinitiivistä (mts. 285-286) mutta ei ainuttakaan vastaavassa funktiossa olevaa TEN-rakennetta (esim. mts. 355-356). Keinon instruktiivi (sekä tavan adessiivi ja instruktiivi) edustuu Räsäsen aineistossa vain erilaisina NP-rakenteina. Räsänen myös toteaa, että "[t]avallisimmin infinitiivimuotoinen sana on kiteytynyt adverbiksi tai adverbin tapaiseksi ilmaukseksi” (mts. 358). Tämä viittaa instruktiivin epäproduktiivisuuteen Kainuun murteissa ja ehkä osin tästä syystä Räsänen ei ole aineistossaan TEN-rakennetta kohdannut. Vaikka siis selvää jakoa ei voi yksiselitteisesti nähdä, niin kartoissa (1a) ja (3b) TEN-rakenteen käyttö tavan ja keinon merkityksissä vaikuttaa keskittyvän enemmän länsimurteisiin. Käyttämäni aineiston valossa näiden käyttöjen alueellisesta jakautumisesta ei voi kuitenkaan sanoa mitään varmaa. 


\section{Aineistolähteet}

DMA Digitaalinen Muoto-opin arkisto. Signumit 747 ja 751 . Käytettävissä Kielipankissa $<$ https://www. kielipankki.fi/>.

LA Lauseopin arkisto. Käytettävissä Kielipankissa $<$ https://www.kielipankki.fi/>.

SMS Suomen murteiden sanakirjan osat 1-8 (kirjainväli A-kurvottaa). Kotimaisten kielten keskus, Helsinki.

\section{Kirjallisuus}

Bergen, Benjamin - Chang, Nancy - Narayan, Shweta 2004: Simulated Action in an Embodied Construction Grammar. Proceedings of the Twenty-Sixth Annual Conference of the Cognitive Science Society, 108-113. Lawrence Erlbaum, Mahwah, NJ.

Cristofaro, Sonia 2003: Subordination. Oxford University Press, Oxford.

Croft, William 1991: Syntactic Categories and Grammatical Relations. The Cognitive Organization of Information. The University of Chicago Press, Chicago.

2001: Radical Construction Grammar: Syntactic Theory in Typological Perspective. Oxford University Press, Oxford.

Fillmore, Charles J. 1989: Grammatical Construction Theory and the Familiar Dichotomies. R. DietRich ja C. F. Graumann (toim.): Language Processing in Social Context, 17-38. Elsevier Science Publishers B. V.

Fried, Mirjam - Östman, Jan-Ola 2004: Construction Grammar. A Thumbnail sketch. Mirjam Fried ja Jan-Ola Östman (toim.): Construction Grammar in a Cross-Language Perspective, 11-86. John Benjamins, Amsterdam.

Genetz, Arvid 1890: Suomen partikkelimuodot [yliopistollinen väitöskirja]. Helsingissä, Suomal. Kirjallis. Seuran kirjapainossa.

Goldberg, Adele E. 2006: Constructions at work: the nature of generalization in language. Oxford University Press, Oxford.

Hamunen, Markus 2012: Koloratiivirakenne, liike ja tapa. Ilona Herlin ja Lari Kotilainen (toim.): Verbit ja konstruktiot, 104-140. Suomi 201. SKS, Helsinki.

Heine, Bernd - Kuteva, Tania 2002: World Lexicon of Grammaticalization. Cambridge University Press, Cambridge.

HerLin, ILONA 1998: Suomen kun. SKST 712. SKS, Helsinki.

Herlin, ILONA - KOTILAINEN, LARI 2005: Itsenäistyvä infinitiivi. 2. infinitiivin inessiivin kehitys kirjakielen aikana. Ilona Herlin ja Laura VISApäÄ (toim.): Elävä kielioppi. Suomen infiniittisten rakenteiden dynamiikkaa, 258-291. SKST 1021. SKS, Helsinki.

_ 2012: Johdatus verbi- ja konstruktiotutkimukseen. Ilona Herlin ja Lari Kotilainen (toim.): Verbit ja konstruktiot, 7-26. Suomi 201. SKS, Helsinki.

Herlin, Ilona - Visapää, LaURA (toim.) 2005: Elävä kielioppi. Suomen infiniittisten rakenteiden dynamiikkaa. SKST 1021. SKS, Helsinki.

Herlin, Ilona - Leino, Pentti - Visapää, Laura 2005: Kas siinä pulma. Ilona Herlin ja Laura ViSAPÄÄ (toim.): Elävä kielioppi. Suomen infiniittisten rakenteiden dynamiikkaa, 9-38. SKST 1021. SKS, Helsinki.

Hilpert, martin 2014: Construction Grammar and its Application to English. Edinburgh University Press, Edinburgh.

Huvmo, Tuomas 1997: Lokatiivit lauseen semanttisessa tulkinnassa. Ajan, omistajan, paikan ja tilan adverbiaalien keskinäiset suhteet suomen kielessä. Turun yliopiston suomalaisen ja yleisen kielitieteen laitoksen julkaisuja 15, Turku.

Iкola, Osmo 1974: Lauseenvastikeoppia. Nykysuomen lauseenvastikkeiden ja niihin verrattavien rakenteiden selvittelyä. Tietolipas 76. SKS, Helsinki.

Ikola, Osmo - Palomäki, Ulla - Koitto, Anna-Kaisa 1989: Suomen murteiden lauseoppia ja tekstikielioppia. SKST 511. SKS, Helsinki. 
ISK = Auli Hakulinen, Maria Vilkuna, Riitta Korhonen, Vesa Koivisto, Tarja Riitta HeinoNEN ja IrJa AlHo 2004: Iso suomen kielioppi. SKS, Helsinki.

Itkonen, Esa - Pajunen, Anneli 2010: Empiirisen kielitieteen metodologia. Suomi 199. SKS, Helsinki. ItKonen, Terho 1974: Ergatiivisuutta suomessa I. Virittäjä 78, 379-398.

1975: Ergatiivisuutta suomessa II. Virittäjä 79, 3-65.

JäÄSKeläInen, Petri 2004: Instrumentatiivisuus ja nykysuomen verbinjohto: semanttinen tutkimus. Jyväskylä studies in humanities 22. Jyväskylän yliopisto, Jyväskylä.

Karlsson, Göran 1995: Suomen kielen tavan adessiivi. Suomi 178. SKS, Helsinki.

Kettunen, LaUri 1949: Hyvää vapaata suomea. Ohjekirja suomen kielen käyttäjille. K. J. Gummerus osakeyhtiö, Jyväskylä.

KIURU, Silva 1989: Kolmannen infinitiivin olosijat ja vanha kirjasuomi. Virittäjä 93, 432-445.

KoIvisto, Vesa 2005: Monikasvoinen - $m$ A ja suomen agenttipartisiipin tausta. Ilona Herlin ja LaURA VISAPÄ̈̈ (toim.): Elävä kielioppi. Suomen infiniittisten rakenteiden dynamiikkaa, 146-172. SKST 1021. SKS, Helsinki.

Kolehmainen, TARU 2003: Rakkaudella - tavan adessiivista. Kielikello 4/2003.

Kotilainen, LARI 2007: Konstruktioiden dynamiikkaa [väitöskirja]. Helsingin yliopiston suomen kielen ja kotimaisen kirjallisuuden laitos, Helsinki.

König, EkKehard 1995: The meaning of converb constructions. Martin Haspelmath ja EkKehard KönIg (toim.): Converbs in Cross-Linguistic Perspective. Structure and Meaning of Adverbial Verb Forms - Adverbial, Participles, Gerunds, 57-95. Mouton de Gryuter, Berlin.

LaITINEn, LeA 1992: Välttämättömyys ja persoona. Suomen murteiden nesessivisten rakenteiden semantiikkaa ja kielioppia. SKST 569. SKS, Helsinki.

LaPPalainen, Tirna 1993: Nykysuomen II infinitivin instruktiivin ja III infinitivin adessiivin syntaksia ja semantiikkaa. Pro gradu -tutkielma. Helsingin yliopiston suomen kielen laitos.

LarjavaAra, MatTi 2007: Pragmasemantiikka. SKST 1077. SKS, Helsinki.

Leino, JaAkko 2001: Antamiskehys kognitiivisena konstruktiona. Pentti Leino, Ilona Herlin, Suvi Honkanen, Lari Kotilainen, JaAkKo Leino ja Maija Vilkkumaa (toim.): Roolit ja rakenteet. Henkilöviitteinen allativi Biblian verbikonstruktoissa, 67-103 [luku 2]. SKST 813. SKS, Helsinki. 2003: Antaa sen muuttua. Suomen kielen permissiivirakenne ja sen kehitys. SKST 900. SKS, Helsinki.

2010: Adele E. Goldberg - Väitöskirjalla klassikoksi. Pentti Haddington ja Jari Sivonen (toim.): Kielentutkimuksen modernit klassikot. Kognitiivinen ja funktionaalinen kielitiede, 71-97 [luku 3]. Gaudeamus, Helsinki.

Leino, Pentti 1993: Polysemia - kielen moniselitteisyys. Kieli 7. Helsingin yliopiston suomen kielen laitos, Helsinki.

LINDÉN, EEVA 1961: Temporaalirakenne suomen murteissa. Virittäjä 65, 194-210.

Luojola, Teemu 2007: Adessiivin funktion päättely paikallisessa kontekstissa. Virittäjä 111, 367-390.

Lyons, John 1979 [1977]: Semantics. Volume 1. Cambridge University Press, Cambridge.

Mikone, Eve 2002: Deskriptiiviset sanat. Määritelmät, muoto ja merkitys. SKST 879. SKS, Helsinki.

NiKANNE, URPO 1997: Suomen infiniittisten adjunktien temporaalinen tulkinta. Virittäjä 101, 338-357.

ONIKKI-RANTAJÄÄsKö, TINA 2001: Sarjoja. Nykysuomen paikallissijaiset olotilanilmaukset kielen analogisuuden ilmentäjinä. SKST 817. SKS, Helsinki.

OntermaA, АKi 2005: Hilsettä ja herrastelua? Toisen infinitiivin instruktiivin ohjailu ja kielenhuollon ideologiat. Ilona Herlin ja LAura Visapä̈̈ (toim.): Elävä kielioppi. Suomen infiniittisten rakenteiden dynamiikkaa. SKST 1021. SKS, Helsinki.

Pajunen, Anneli 2001: Argumenttirakenne: asiaintilojen luokitus ja verbien käyttäytyminen suomen kielessä. Suomi 187. SKS, Helsinki.

Palmer, Frank Robert 1981 [1976]: Semantics. Cambridge University Press, Cambridge.

PekKarinen, Heli 2011: Monikasvoinen TAVA-partisiippi. Tutkimus suomen TAVA-partisiipin käyttökonteksteista ja verbiliittojen kieliopillistumisesta [väitöskirja]. Helsingin yliopiston suomen kielen, suomalais-ugrilaisten ja pohjoismaisten kielten ja kirjallisuuksien laitos, Helsinki.

Penttilä, Aarni 1957: Suomen kielioppi. Werner Söderström Osakeyhtiö, Helsinki. 
Pokela, Hanna 2005: Kirjakieltä kehittäen - Lönnrotin 2. infinitiivin instruktiivi. Ilona Herlin ja LAURA VISAPäÄ (toim.): Elävä kielioppi. Suomen infiniittisten rakenteiden dynamiikkaa. SKST 1021. SKS, Helsinki.

Rosch, Eleanor 1978: Principles of Categorization. Eleanor Rosch ja Barbara B. Lloyd (toim.): Cognition and categorization, 28-49. Lawrence Erlbaum, Hillsdale, NJ.

RäsäNEN, MATTI 2010: Päivä päivältä enemmän ja enemmän. Suomen toistokonstruktioita. Suomen kielen, suomalais-ugrilaisten ja pohjoismaisten kielten ja kirjallisuuksien laitos, Helsingin yliopisto. Yliopistopaino, Helsinki.

RÄSÄNEN, SEPPO 1972: Kainuun murteiden kaasussyntaksi. SKST 308. SKS, Helsinki.

SaArimaA, E. A. 1967: Kielenopas. Seitsemäs painos, tarkistanut Paavo Pulkkinen. WSOY, Helsinki.

SAARnivaAra, PANU 1998: "Vaivaa nähden perehtymällä kirjallisuuteen". Nykysuomen toisen infinitiviin instruktiivin ja kolmannen infinitiivin adessiivin ja siitä annettujen suositusten toteutuminen. Pro gradu -tutkielma. Suomalaisen ja yleisen kielitieteen laitos, Turun yliopisto, Turku.

SETÄLÄ, E. N. 1922: Suomen kielen lauseoppi. Oppikouluja varten. Kymmenes, tarkistettu painos. Kustannusosakeyhtiö Otava, Helsinki.

SIIKKI, IlONA 1997: Tapaa ja keinoa ilmaisevat II infinitiivin instruktiivi ja III infinitiivin adessiivi nykysuomessa. Pro gradu -tutkielma. Tampereen yliopiston suomen kielen laitos.

Siro, PaAvo 1964: Suomen kielen lauseoppi. Tietosanakirja Oy, Helsinki.

SKS = Suomalaisen Kirjallisuuden Seura

SKST = Suomalaisen Kirjallisuuden Seuran Toimituksia

Steels, LuC - van Trijp, Remi 2011: How to make construction grammars fluid and robust. LuC Steels (toim.): Design Patterns in Fluid Construction Grammar, 301-330. John Benjamins, Amsterdam.

Talmy, LeOnard 2003 [2000]: Toward a Cognitive Semantics, Volume I: Concept Structuring Systems. The MIT Press, Cambridge.

Taylor, John R. 1995: Linguistic Categorization. Prototypes in Linguistic Theory. Second Edition. Clarendon Press, Oxford.

ValiJärvi, RiItTa-LiIsa 2007: A Corpus-Based Study on the Degree of Lexicalizationand Grammaticalization of Finnish Converbs [väitöskirja]. Uppsala Universitet.

VILKUnA, MARIA 1989: Free word order in Finnish. Its syntax and discourse functions. SKST 500. SKS, Helsinki.

VISAPÄÄ, LAURA 2008: Infinitiivi ja sen infiniittisyys. Tutkimus suomen kielen itsenäisistä A-infinitiivikonstruktioista. SKST 1181. SKS, Helsinki.

\section{MARKUS HAMUNEN: Juosten or juoksemalla? Semantics and dialectal distribution of non-finite TEN- and MALLA-constructions}

This paper concentrates on Finnish TEN- (juosten 'by running') and MALLA-constructions (juoksemalla 'by running, by means of running'), two of the less studied non-finites among Finnish infinitive system. Most of the research or scholarly papers on these infinitives have been limited to intuition-based (autonomic) analysis (e.g. Siro 1964), prescriptive grammar or standardization of written language (e.g. Kettunen 1949; Saarimaa 1967). In descriptive grammars, however, their depictions have somehow been heterogeneous and approximate (e.g. Setälä 1922; Penttilä 1957; Karlsson 1995), and the meaning of these infinitives has been associated to manner and means in general without making an explicit difference (e.g. ISK). Conceptually, the functions of both manner and means are related to the meaning of 'how': the former adds attributive meanings to a finite verb clause (cf. adjectives as attributes) and the latter is a verbal intermediary in contexts of change, causation and force dynamics (cf. nouns as instruments). Generally, manner is associated to the paradigmatic level and means to the syntagmatic level. 
The main issue in this paper is the semantic differences between TEN- and MALLA-constructions and their assumed division of labor on 'how' meanings. It has been argued that it is not morphological forms of the infinitives - the te-infinitive instructive (TEN) and the $m A$-infinitive adessive (MALLA) - that carry some conventionalised and clear-cut manner/means meaning, but merely these functions emerge in certain syntactic contexts. As these infinitive constructions act as adjuncts, their semantic interpretations are highly depended on local syntactic contexts built by a finite verb and its arguments.

In order to delve deeper into semantic functions in colloquial Finnish (and eschew warps of intuition), three different dialect corpuses have been used for empirical data: the Digital Morphology Archive (DMA, Digitaalinen muoto-opin arkisto), the Syntax Archive (LA, Lauseopin arkisto), and the dictionary of Finnish dialects Suomen murteiden sanakirja (SMS). There are altogether over 1,400 instances of TEN and over 1,900 instances of MALLA.

In the light of the data, the semantic functions of TEN and MALLA partly overlap and are partly independent of each other. Both have proper (attributive) manner usages, especially in contexts where a finite and an infinitive verb are lexically in a hyponymic relationship (e.g. hoeperrellen käveli 'walked staggering', jäpöittelemällä kävelöö 'walks in a stiff and clumsy way'). Intermediary means usages are found in both infinitives as well, but there is a stronger tendency to use MALLA than TEN (e.g. see kert selvittim puhumalk kyl 'in that time (we) dealt with it by speaking'). A certain semantic subgroup of means, the so-called method function, is only found in MALLA (e.g. onkimalla [pyydettiin kalaa] 'fishing with a hook and a line [was the fish caught]', cf. by fishing net $\sim$ by troling etc.). In the similar way, the Ten infinitive has its own function, i.e. an interpretation of attendance (e.g. tuli kiroten '(s/he) came and cursed (while coming)') which is not found in MALLA.

As manner and means are conceptually separate 'how' dimensions, and the functions of TEN and MALLA are are contextually derived, it can be expected that they have partly the same and partly separate usages. However, one factor that is unexpected is that dialect data do not show any clear areal distribution between the overlapping functions of TEN and MALLA. This is against implications argued in the previous research (e.g. Räsänen 1972; Kiuru 1989).

Markus Hamunen

markus.hamunen@helsinki.fi

Suomen kielen, suomalais-ugrilaisten ja pohjoismaisten kielten ja kirjallisuuksien laitos 00014 Helsingin yliopisto 
Liite

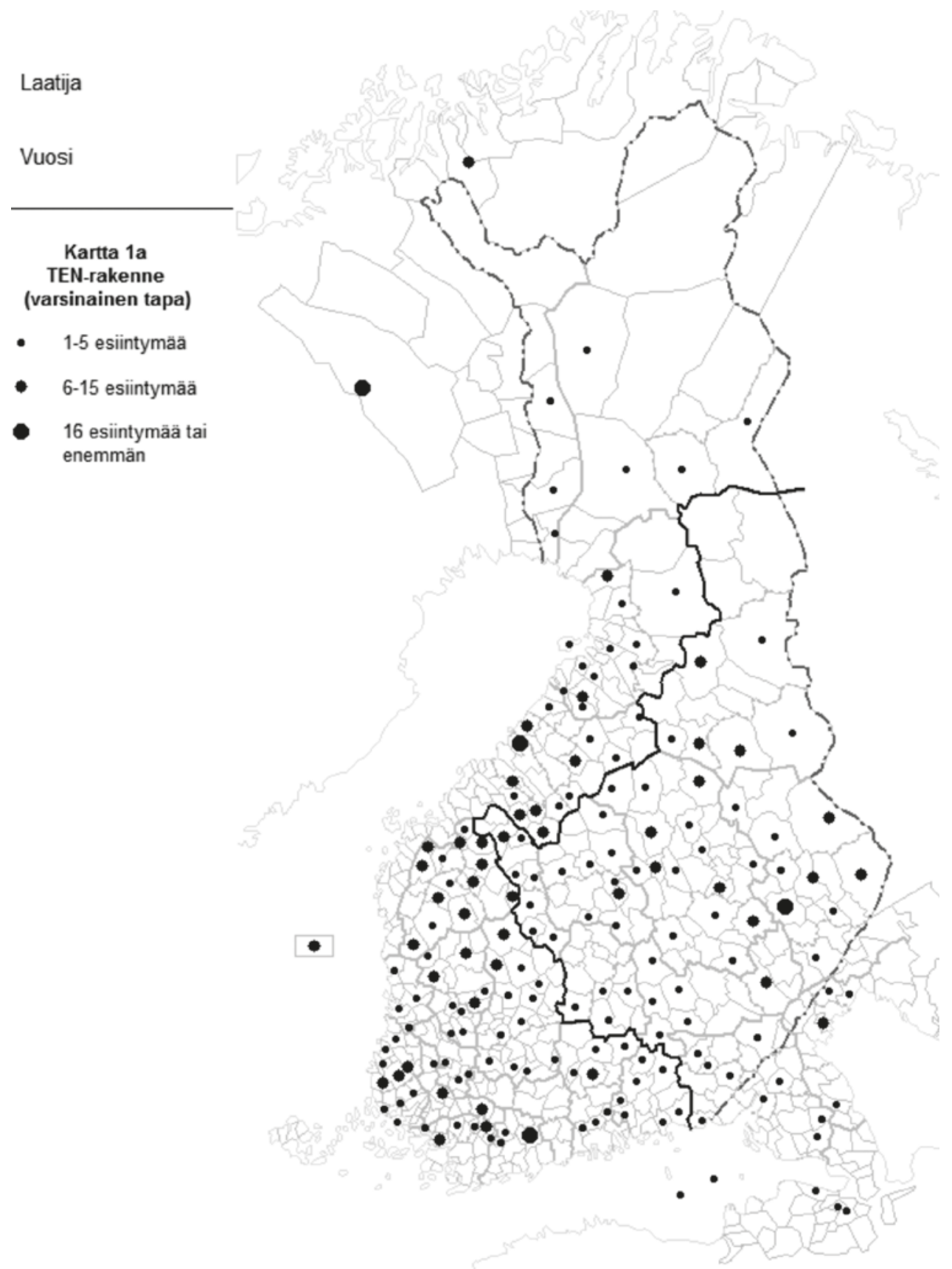


Laatija

Kartta 1b

MALLA-rakenne

(varsinainen tapa)

- $\quad$ 1-5 esiintymäă

- 6-15 esiintymäă

- 16 esiintymäă tai enemmän

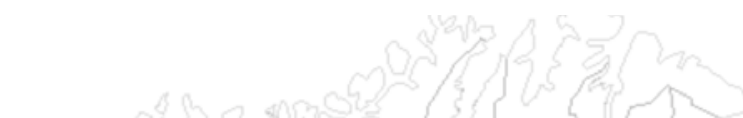

\begin{tabular}{|c|c|}
\hline \multicolumn{2}{|c|}{ Vuosi } \\
\hline & $\begin{array}{l}\text { Kartta 1b } \\
\text { ALLA-rakenne } \\
\text { rsinainen tapa) }\end{array}$ \\
\hline & $1-5$ esiintymää \\
\hline & 6-15 esiintymää \\
\hline & $\begin{array}{l}16 \text { esiintymäả ta } \\
\text { enemmân }\end{array}$ \\
\hline
\end{tabular}

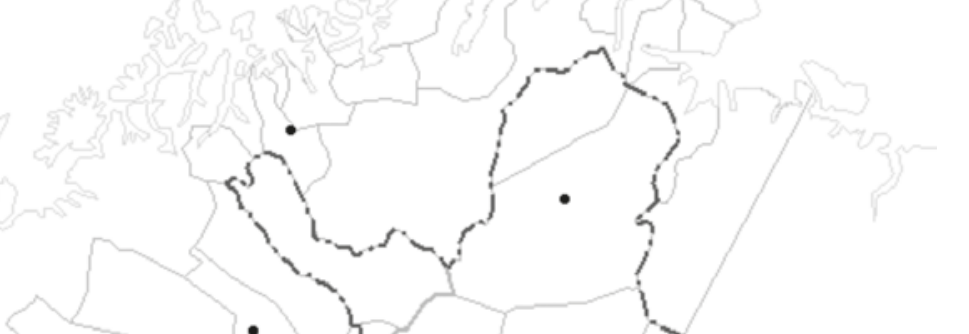




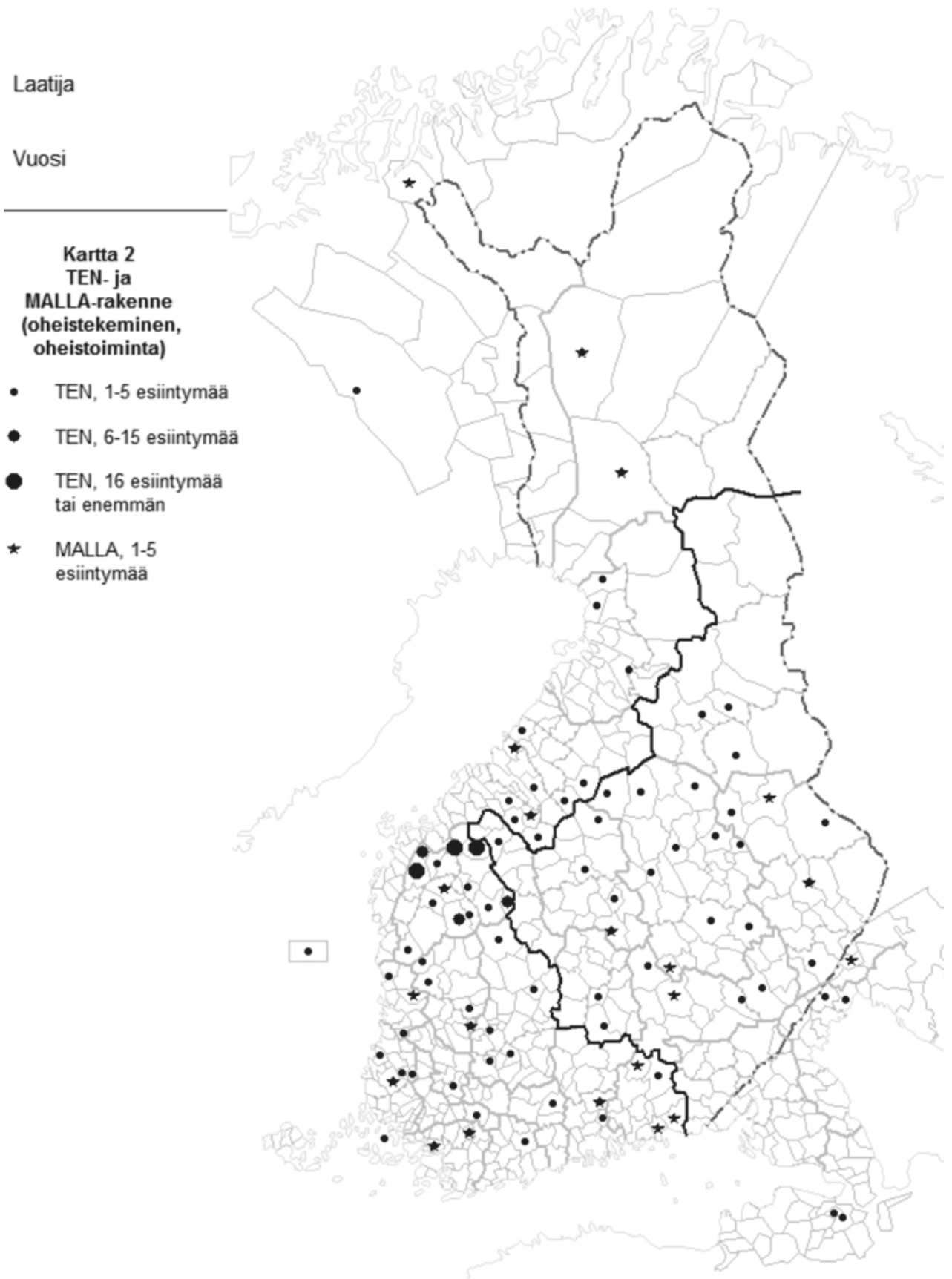


Laatija

Kartta 3a

MALLA-rakenne (keino)

- $\quad 1-5$ esiintymää

- 6-15 esiintymää

- 16 esiintymää tai enemmän

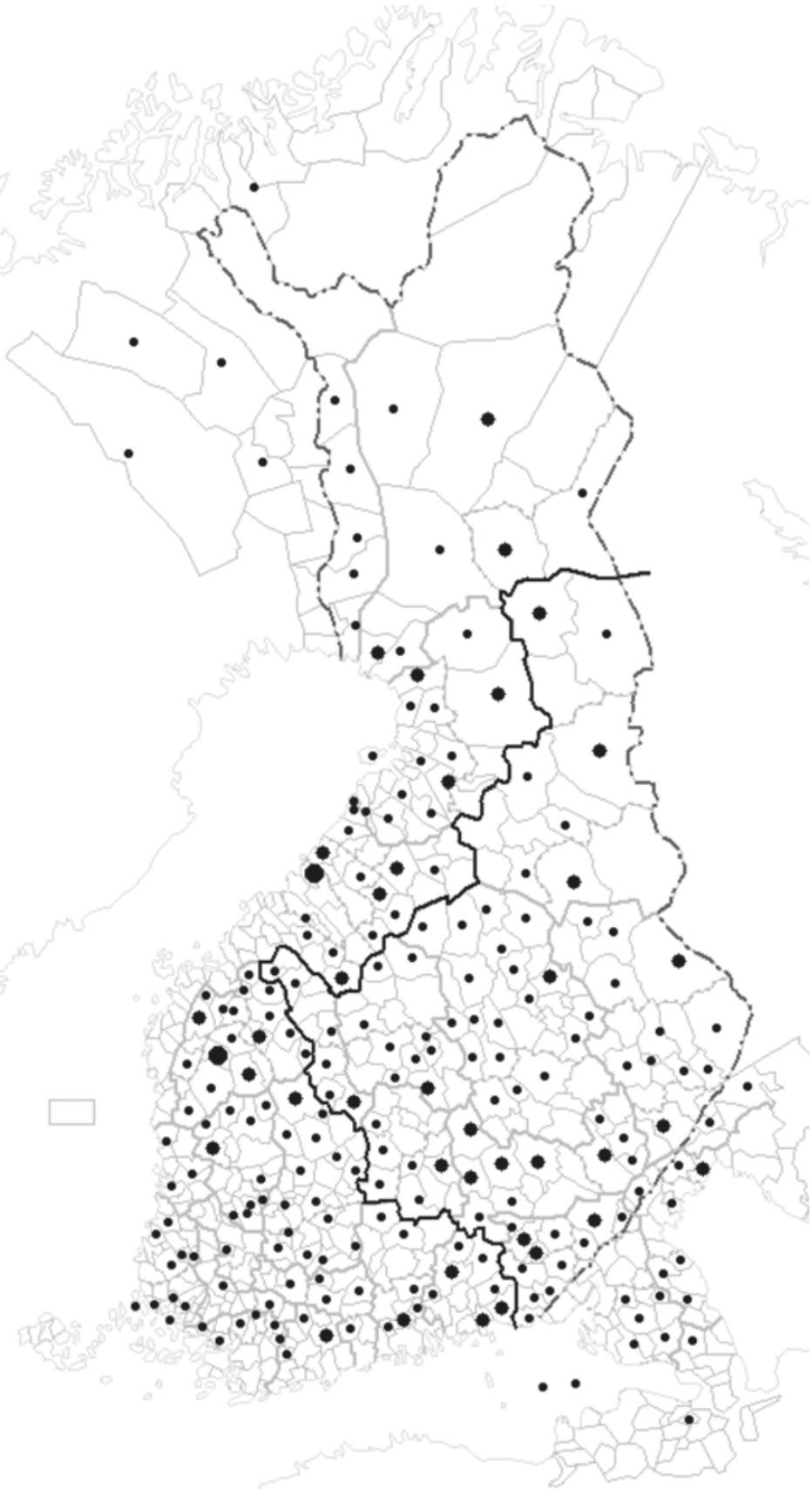




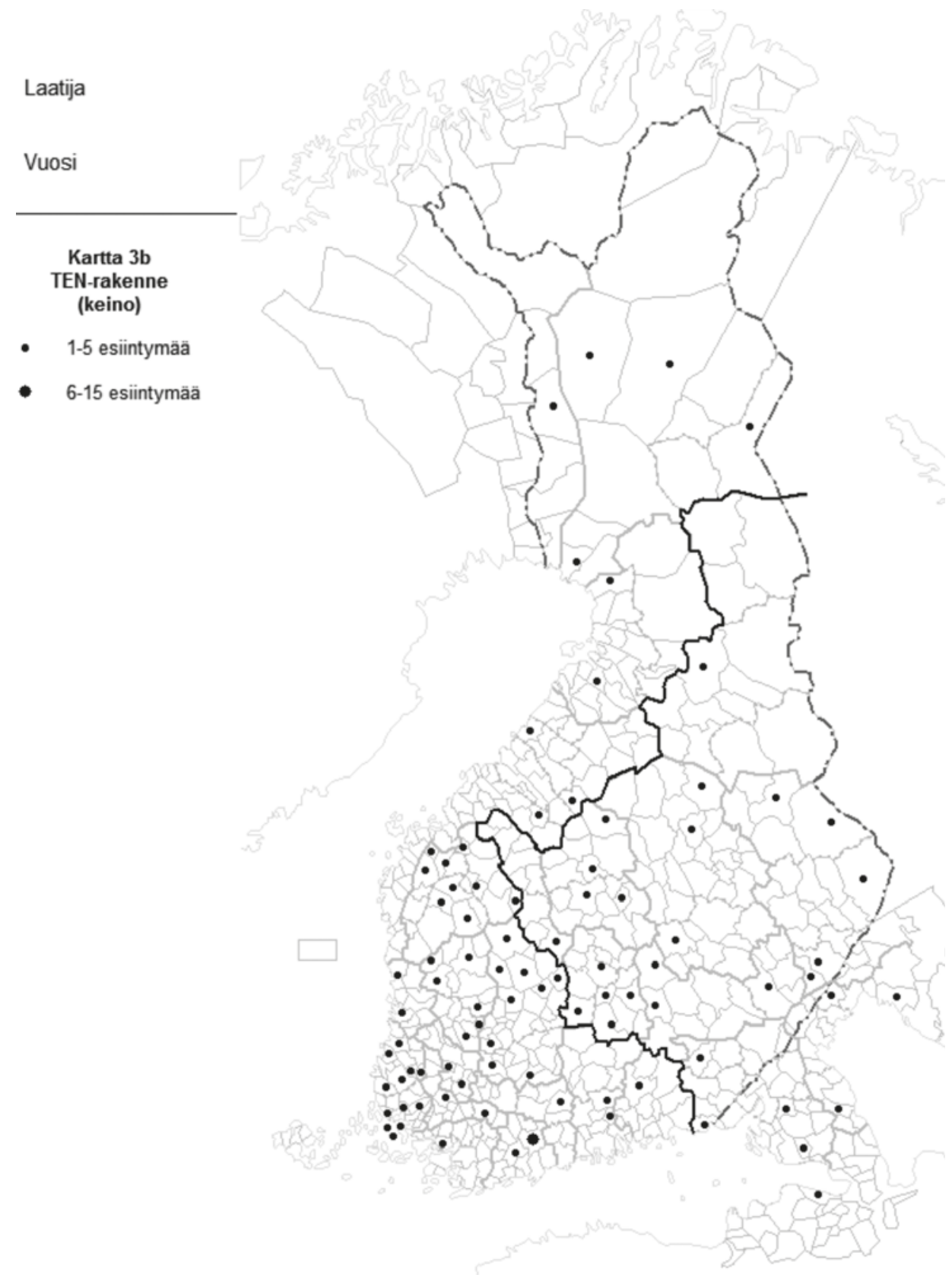

